\title{
Measurements of air pollution emission factors for marine transportation in SECA
}

\author{
B. Alföldy ${ }^{1}$, J. B. Lööv ${ }^{1}$, F. Lagler ${ }^{1}$, J. Mellqvist ${ }^{2}$, N. Berg ${ }^{2}$, J. Beecken ${ }^{2}$, H. Weststrate ${ }^{3}$, J. Duyzer ${ }^{3}$, L. Bencs ${ }^{4,5}$, \\ B. Horemans ${ }^{4}$, F. Cavalli ${ }^{1}$, J.-P. Putaud ${ }^{1}$, G. Janssens-Maenhout ${ }^{1}$, A. P. Csordás ${ }^{6}$, R. Van Grieken ${ }^{4}$, A. Borowiak ${ }^{1}$, and \\ J. Hjorth ${ }^{1}$ \\ ${ }^{1}$ European Commission, Joint Research Centre, Ispra (VA), Italy \\ ${ }^{2}$ Chalmers University of Technology, Göteborg, Sweden \\ ${ }^{3}$ The Netherlands Organization for Applied Scientific Research, Utrecht, the Netherlands \\ ${ }^{4}$ Department of Chemistry, University of Antwerp, Antwerp, Belgium \\ ${ }^{5}$ Institute for Solid State Physics and Optics, Wigner Research Centre for Physics, Hungarian Academy of Sciences, \\ Budapest, Hungary \\ ${ }^{6}$ Centre for Energy Research, Hungarian Academy of Sciences, Budapest, Hungary
}

Correspondence to: B. Alföldy (balint.z.alfoldy@gmail.com)

Received: 14 October 2012 - Published in Atmos. Meas. Tech. Discuss.: 20 December 2012

Revised: 24 April 2013 - Accepted: 30 May 2013 - Published: 24 July 2013

\begin{abstract}
The chemical composition of the plumes of seagoing ships was measured during a two week long measurement campaign in the port of Rotterdam, Hoek van Holland The Netherlands, in September 2009. Altogether, 497 ships were monitored and a statistical evaluation of emission factors $\left(\mathrm{g} \mathrm{kg}^{-1}\right.$ fuel) was provided. The concerned main atmospheric components were $\mathrm{SO}_{2}, \mathrm{NO}_{2}, \mathrm{NO}_{\mathrm{x}}$ and the aerosol particle number. In addition, the elemental and water-soluble ionic composition of the emitted particulate matter was determined. Emission factors were expressed as a function of ship type, power and crankshaft rotational speed. The average $\mathrm{SO}_{2}$ emission factor was found to be roughly half of what is allowed in sulphur emission control areas (16 vs. $30 \mathrm{~g} \mathrm{~kg}^{-1}$ fuel), and exceedances of this limit were rarely registered. A significant linear relationship was observed between the $\mathrm{SO}_{2}$ and particle number emission factors. The intercept of the regression line, $4.8 \times 10^{15}(\mathrm{~kg} \text { fuel })^{-1}$, gives the average number of particles formed during the burning of $1 \mathrm{~kg}$ zero sulphur content fuel, while the slope, $2 \times 10^{18}$, provides the average number of particles formed with $1 \mathrm{~kg}$ sulphur burnt with the fuel. Water-soluble ionic composition analysis of the aerosol samples from the plumes showed that $\sim 144 \mathrm{~g}$ of particulate sulphate was emitted from $1 \mathrm{~kg}$ sulphur burnt with the fuel. The mass median diameter of sulphate particles estimated from the measurements was $\sim 42 \mathrm{~nm}$.
\end{abstract}

\section{Introduction}

Although shipping in general is a very energy efficient way to transport goods, the increase in international ship traffic and the relatively high $\mathrm{SO}_{\mathrm{X}}\left(\mathrm{SO}_{2}+\mathrm{SO}_{3}\right)$ and $\mathrm{NO}_{\mathrm{x}}\left(\mathrm{NO}+\mathrm{NO}_{2}\right)$ emission factors (EFs) of ship engines have raised concerns on the impact of these emissions on the environment and human health. The contribution of ships to global $\mathrm{NO}_{\mathrm{x}}$ emissions is about $15 \%$, while $4-9 \%$ of the global $\mathrm{SO}_{2}$ emissions can be attributed to ships (Eyring et al., 2010). Due to its significant contribution to the anthropogenic $\mathrm{SO}_{2}$ emission, global shipping might also play an important role in climate change. While radiative forcing (RF) of shipping generated $\mathrm{CO}_{2}$ is only $2 \%$ of the total anthropogenic $\mathrm{CO}_{2} \mathrm{RF}$, the direct aerosol (cooling) effect of shipping emitted sulphate is about $8 \%$ of the total anthropogenic direct aerosol RF. In addition, some calculations estimate that shipping related indirect aerosol effects can exceed $40 \%$ of the total indirect aerosol effects of anthropogenic sources (Eyring et al., 2010). Since the sulphur content of heavy fuel oil will be radically reduced in the coming years, its climatic consequences must also be considered. On the other hand, any decrease in the global $\mathrm{SO}_{2}$ emission is generally beneficial for the environment and human health. $\mathrm{SO}_{2}$ emissions increase the acidity of the atmosphere, thereby damaging living organs and 


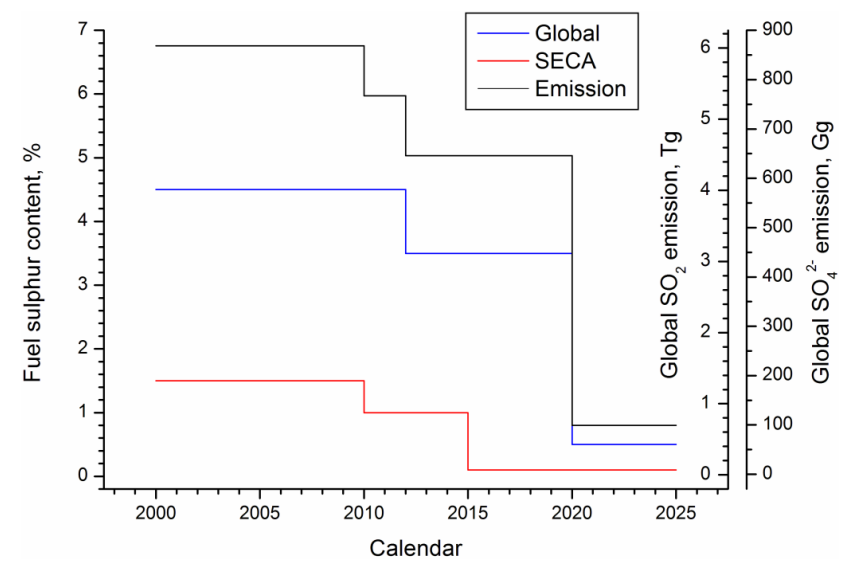

Fig. 1. Timeline for the reduction of sulphur content in fuels, globally and in SECAs. Calculated and predicted global $\mathrm{SO}_{2}$ and $\mathrm{SO}_{4}{ }^{2-}$ emission are also plotted in accordance with the change of the estimated global average of fuel sulphur content.

producing acid rain (IPCC, 2007). In addition, the secondary formed sulphate aerosol contributes to the PM load, which adverse health effect on humans is well documented (Cohen et al., 2005; Cofala et al., 2007; Corbett et al., 2007). The complexity of the environmental effects of atmospheric $\mathrm{SO}_{2}$ requires accurate consideration of ship emissions in the light of mitigation policies.

Sulphur is a mineral constituent of crude oil, ranging from 0.5 up to $5 \%$ by mass, depending on the quality of the oil. During combustion of crude oil, the mineral sulphur is oxidised mainly to $\mathrm{SO}_{2}$ and in minor quantities to $\mathrm{SO}_{3}$ and sulphuric acid.

Nitrogen oxides $\left(\mathrm{NO}_{\mathrm{x}}\right)$ are also emitted during combustion as a result of the oxidation of atmospheric $\mathrm{N}_{2}$ and the small fraction of nitrogen in the fuel. $\mathrm{NO}_{\mathrm{x}}$ contributes to acidification and to the formation of tropospheric ozone, which can be harmful for human health and vegetation at ground level.

Atmospheric emissions from ships have not been the focus of regulations until recent years; the lack of regulations allowed the use of heavy fuel oil (HFO), the residue with a typical high sulphur content which remains after refining crude oil. Also the emissions of nitrogen oxides from ships have not been regulated until recently.

As a result of the harmful environmental effects related with the combustion of HFO, the International Maritime Organisation (IMO) regulated the sulphur content of the fuel and $\mathrm{NO}_{\mathrm{x}}$ emission rates through the Annex VI of the MARPOL protocol, which entered into force in 2005. At the time of this study, the global limit for all seas and oceans was $4.5 \%$, except in Sulphur Emission Control Areas (SECAs), where it was $1.5 \%$. These limit values will change in the near future; in 2012, the global $4.5 \%$ has been reduced to $3.5 \%$, from which it will be reduced to $0.5 \%$ by 2020 ; the $1.5 \%$ in SECAs was reduced to $1 \%$ in 2010 and will be further decreased to $0.1 \%$ from 2015 onwards (Fig. 1).

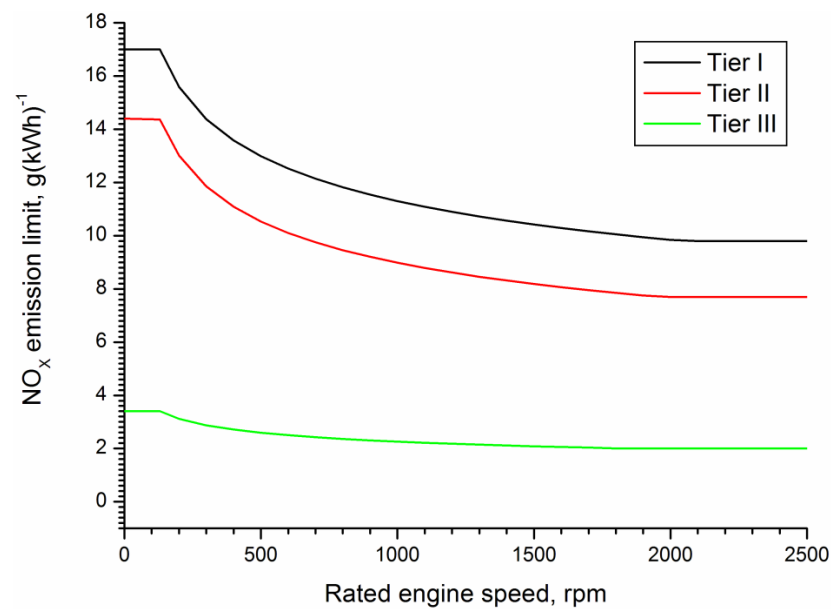

Fig. 2. $\mathrm{NO}_{\mathrm{x}}$ emission limits, at different rated engine speeds, for ships built after 2000 (Tier I), after 2011 (Tier II), and after 2016 in emissions control areas (Tier III).

In the case of $\mathrm{NO}_{\mathrm{x}}$, the engine power-weighted emission rate is limited by the MARPOL rules. This regulation is more complex, since the limit depends on the fuel efficiency of the used engine. Large ships, such as container vessels and tankers usually run with slow speed engines with a rated engine speed of around $100 \mathrm{rpm}$. These ships are fuel efficient (down to $160 \mathrm{~g} \mathrm{kWh}^{-1}$ ), but due to the long residence time of the gas in the combustion space they produce high amounts of $\mathrm{NO}_{\mathrm{x}}$. Ferries and intermediate sized ships usually use medium speed engines with a rated engine speed of around $500 \mathrm{rpm}$. These engines are less fuel efficient (180$200 \mathrm{~g} \mathrm{kWh}^{-1}$ ), but on the other hand produce less $\mathrm{NO}_{\mathrm{x}} \mathrm{com}-$ pared to the slow speed engines. Ships built after 2000 have to fulfil the IMO Tier I emission values regarding $\mathrm{NO}_{\mathrm{x}}$, and by 2011 the emission for new ships should be even $20 \%$ lower (Tier II, see Fig. 2). Also, ships built between 1990 and 2000 will be forced to retrofit $\mathrm{NO}_{\mathrm{x}}$ abatement equipment, if a cost effective upgrade is available. Tier III is not yet ratified, but this limit will become valid in special $\mathrm{NO}_{\mathrm{x}}$ emission control areas (NOXECAs) and for ships built during or after 2016. Detailed information about the technical aspects and expected impacts of the IMO regulations on $\mathrm{NO}_{\mathrm{x}}$ emissions can be found in a study published by IMO (2009).

Due to its important environmental impact, the number of ship emission studies is growing year by year. In the present work we use results of Hobbs et al. (2000), Sinha et al. (2003), Chen et al. (2005), Agrawal et al. (2008), Petzold et al. (2008), Moldanova et al. (2009) and Murphy et al. (2009). These studies provide a comprehensive description of ship emissions; however, due to the experimental difficulties they could focus on only one or a relatively small $(<10)$ number of ships. These studies demonstrate that the emission rates are highly variable between the ships. For this reason the contribution of marine transportation to the global budget of air pollutants can only be assessed based 


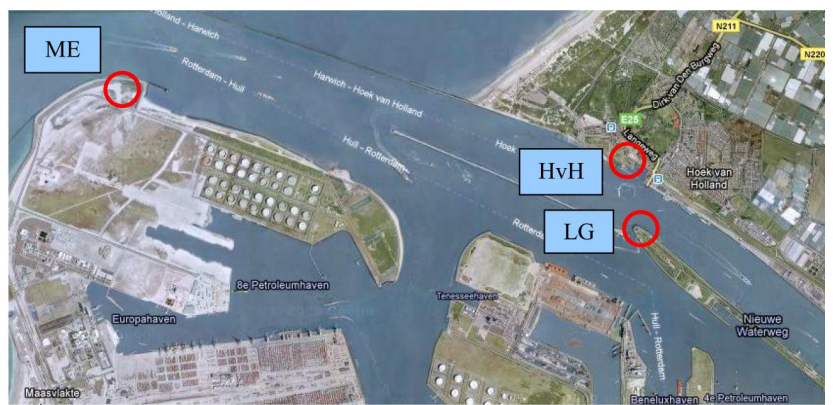

Fig. 3. Map of the measurement area, with marks at the 3 measurement sites. HvH - Hoek van Holland, LG - Landtong, ME Maasvlakte.

on a statistically representative fleet. Despite the high international interest, only a few such studies have been performed so far (see e.g. Williams et al., 2009; Lack et al., 2009). This work aimed at reducing the white spots on the map and characterise the ship emission statistically under the particular conditions found in a SECA. However, a result can be extrapolated to provide an estimate for global shipping, as we present relationships between the fuel sulphur ratio and sulphate EFs. Scaling up by the fuel sulphur ratio, globally valid EFs can be derived, while emission factors for $\mathrm{NO}_{\mathrm{x}}$ and non-sulphuric particles can be considered as globally valid value as they depend only slightly on fuel type (see discussion below).

Some of the co-authors applied previous in situ plume measurements, as discussed in detail below. The Netherlands Organisation for Applied Scientific Research (TNO) organised several short measurement campaigns at the coast of the North Sea in order to retrieve real EFs of ship combustion processes (Duyzer et al., 2006; Segers and Duyzer, 2007). Chalmers University of Technology performed in situ plume investigation campaigns in the Baltic region with similar purposes (Mellqvist et al., 2008; Mellqvist and Berg, 2010). In these studies (as in the present work) $\mathrm{EFs}$ for $\mathrm{NO}_{\mathrm{x}}, \mathrm{SO}_{2}$ and particulate matter (PM) were retrieved. In addition, knowing that the main part of the fuel sulphur content is emitted as $\mathrm{SO}_{2}$, the sulphur content of the fuel can be derived from the $\mathrm{SO}_{2} \mathrm{EF}$. This can be an efficient tool in the hands of authorities to check the sulphur limit compliance of the ships remotely, without boarding and taking fuel samples.

\section{Experimental}

\subsection{Measurement campaign}

A two-week measurement campaign was conducted at the shores of the entrance channel to the Port of Rotterdam in Hoek van Holland, the Netherlands, from 17 September 2009 to 29 September 2009. In order to catch the exhaust plumes of the passing ships on the downwind shore of the channel,

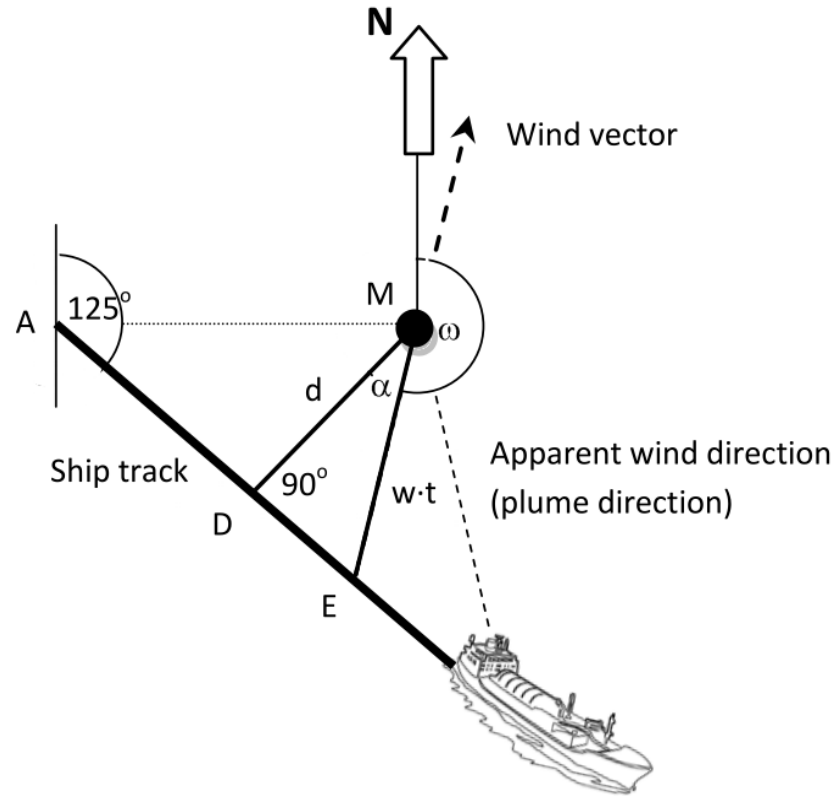

Fig. 4. Geometric scheme of the plume measurement. A thick black line represents the ship's track. Point M marks the measurement location; point $\mathrm{D}$ is the position of the ship when $d$ distance was measured; the measured plume parcel was emitted at point $\mathrm{E} ; w, \omega$ and $t$ are the wind speed, wind direction and plume's age, respectively. The direction of the channel was $125^{\circ}$ at the measurement point.

the sampling location was flexibly switched according to the wind direction. One sampling location was selected at the northern side of the "Nieuwe Waterweg" $(\mathrm{HvH})$, while another was chosen on a land stretch at the southern side, designated as "Landtong" (LG, Fig. 3). Additionally, a location at the "Maasvlakte" (ME), at the extreme southwestern side of the channel has been used twice. It should be mentioned that the traffic at the entrance of the channel is split into two branches: the most frequently sampled northern channel is connected inland to the city of Rotterdam, while the southern leads to several petrol and food terminals and the Europort.

The measurements were concurrently performed by three independent mobile laboratories of the Joint Research Centre (JRC), TNO and Chalmers, each of them being deployed in vans. All of these labs were equipped with a complete air quality monitoring system for the measurement of $\mathrm{CO}_{2}$ and gaseous air pollutants $\left(\mathrm{SO}_{2}, \mathrm{NO}_{2}\right.$ and $\left.\mathrm{NO}_{\mathrm{X}}\right)$ at $2-5 \mathrm{~m}$ above the ground. In addition, JRC measured $\mathrm{SO}_{2}$ and $\mathrm{CO}_{2}$ by a parallel system at $15 \mathrm{~m}$ above the ground, as well as the total aerosol number concentration at ground level $(\sim 1 \mathrm{~m})$. Aerosols were also sampled for chemical analysis as described below. Besides these fixed point measurements, the group of Chalmers performed chasing measurements by a coast guard helicopter and a port service boat. The results of these measurements are reported in other papers (Mellqvist and Berg, 2011; Berg et al., 2012). 


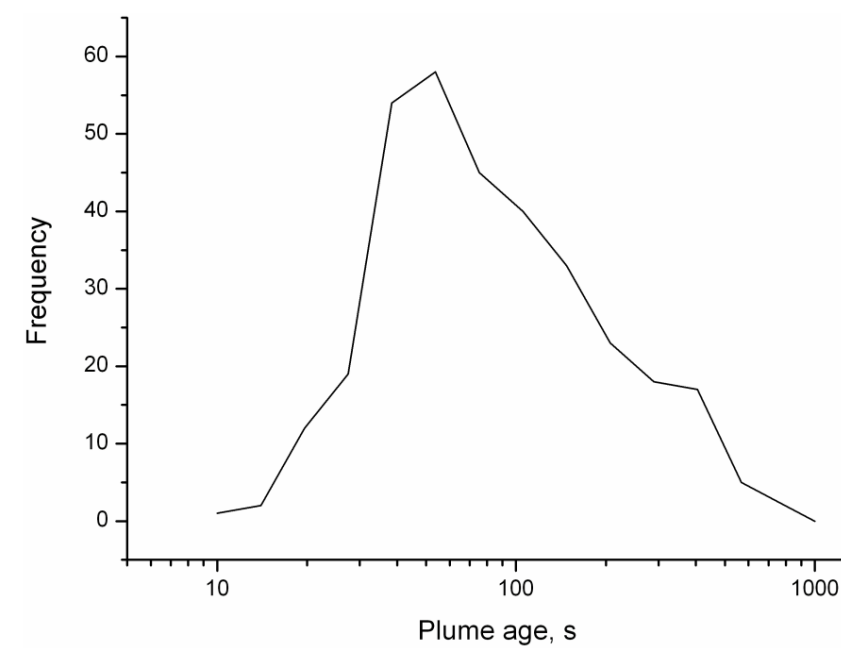

Fig. 5. Distribution of the ages of the measured plumes.

During the campaign, the measurement systems were running continuously, except while moving the labs from one sampling point to the other. The identification of the ships was performed by human observations during daytime. Particular care was paid to annotate AIS (Automated Information System) information on the ships sailing by (name, IMO number, speed and ships' characteristics).

The distance of the passing ships was measured by a Leica 1600-B CRF laser range finder with more than $1450 \mathrm{~m}$ measurement range. Since the total width of the channel is around $1400 \mathrm{~m}$ at the measurement point $(\mathrm{HvH})$, distance of ships sailing in both the northern and the southern part of the channel could be determined. During the distance measurement the shortest distance was taken, when the ship was at the closest point of the measurement location.

The distance of the passing ships was applied for plume age calculation. Figure 4 shows the geometric scheme of the plume measurement. The thick black line represents the track of the ships. Point M marks the measurement location, point $\mathrm{D}$ is the position of the ship when the distance measurement was taken, and the measured plume parcel was emitted at point $\mathrm{E}$. The distance travelled by the measured air parcel can be expressed as $w \cdot t$, where $w$ is the wind speed, while $t$ is the age of the measured plume. The direction of the channel was $125^{\circ}$ at the measurement point, while wind direction is marked by $\omega$. The $w \cdot t$ distance can be determined from the MDE triangle as follows:

$w \cdot t=\frac{d}{\cos a}$,

where $d$ is the measured distance of the passing ship and $a$ can be expressed by the wind direction $\omega$ considering the basic geometrical rules in ADM and MDE triangles.

The distribution of plume ages expressed from Eq. (1) is presented in Fig. 5. It can be seen that the main plume age was $100 \mathrm{~s}$, and no plume was older than $15 \mathrm{~min}$.

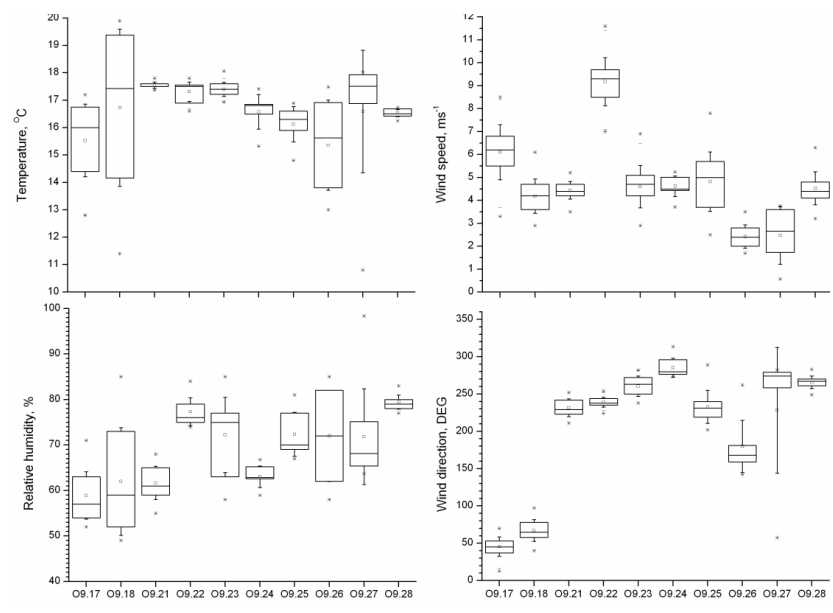

Fig. 6. Summary of the meteorological conditions of the campaign as it can be reflected by temperature (top left panel), relative humidity (bottom left), wind speed and direction (top right and bottom right panels). Squares and horizontal bars represent the means and medians, respectively, while boxes show the range between the 1st and 3rd quartile. Error bars represent the standard deviations and stars show the minimum and maximum values.

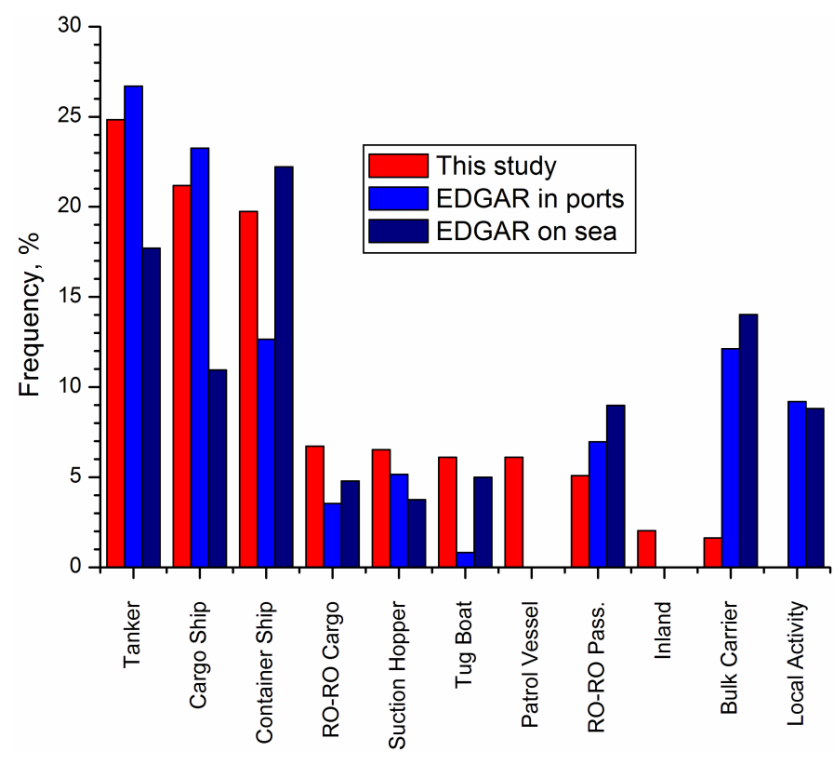

Fig. 7. Distribution of the studied ships according to duty, compared with EDGARv4.2 database.

\subsection{Meteorological conditions and sampling strategy}

The meteorological conditions during the campaign are summarised in Fig. 6. Mean, median, first and third quartile, standard deviation, as well as minimum and maximum values are presented for four parameters such as temperature, relative humidity, wind speed and direction. The values concern the periods, when plume measurements were taken, namely from 08h00 to 20:00 CEST each day generally. Unfortunately data for the 19th, 20th and 29th were lost due to technical reasons. 
During the first third of the campaign, from 17th to 21 st, the wind direction was E, NE. The measurement location was LG that was found to be an ideal location for sampling the northern part of the channel. On the first day the wind was strong with $6 \mathrm{~m} \mathrm{~s}^{-1}$ mean that gradually decreased during the next days. On the 19th and 20th Chalmers measured at the ME point that has the open sea in the upwind direction providing low background concentrations.

On the 21st around noon the wind direction turned to S-SW and it was decided to move the measurement point to $\mathrm{HvH}$. In this location both the northern and the southern part of the channel could be measured. On the next day the wind became stormy with a mean speed of $9 \mathrm{~m} \mathrm{~s}^{-1}$. This condition favoured the measurements by transporting slightly diluted fresh plumes to the measurement location. The following days were characterised by moderate wind speed, and the wind direction turning to $\mathrm{W}$ and than $\mathrm{NW}$ creating more and more difficult conditions for plume sampling. By the NW wind direction the wind blew parallel to the channel, which meant that only a very diluted plume could be sampled. EFs calculations from the most diluted plumes were loaded by high uncertainties, these results were discarded from the dataset. On the 27th the conditions did not favour the measurements (low wind speed, changing direction), the data had to be discarded.

The weather was sunny and dry during the whole campaign, except the 22nd, 25th and 29th which were covered. On the 29th there was a light shower that did not disturb the measurement.

\subsection{Instrumentation}

$\mathrm{SO}_{2}$ concentrations were monitored using a THERMO ELECTRON model 43C Trace Level UV fluorescent analyser (Thermo Electron Corporation, Franklin, MA, USA). The intensity of the fluorescent radiation, detected by a photomultiplier tube, is proportional to the $\mathrm{SO}_{2}$ concentration sampled in the ambient air. However, other atmospheric gases, such as NO and polycyclic aromatic hydrocarbons (PAHs) are also fluorescing, hence they can cause interference on the determination of $\mathrm{SO}_{2}$. $\mathrm{NO}$ concentrations may lead to a bias in the results typically in the order of $2-3 \%$ of the NO reading, hence $100 \mathrm{ppmv} \mathrm{NO}$ will be interpreted as 2-3 ppmv $\mathrm{SO}_{2}$, this was corrected during the data treatment. The interference by PAHs was avoided by a 'hydrocarbon kicker'. In order to achieve the required response time, the diameter of the critical orifice had to be enlarged to allow a faster sampling flow $\left(\sim 1.5 \mathrm{~L} \mathrm{~min}^{-1}\right)$. Also the time constant in the software of the $\mathrm{SO}_{2}$-analyser was set to $1 \mathrm{~s}$. With these settings, the response time $\left(t_{90}\right)$ of the instrument was around $15 \mathrm{~s}$. For calibration, a reference gas mixture of $100 \mathrm{ppbv}$ $\mathrm{SO}_{2}$ in synthetic air was applied, while $\mathrm{SO}_{2}$-free synthetic air was used for the baseline (zero) calibration. Instrument accuracy: $\pm 10 \%$.
$\mathrm{CO}_{2}$ concentrations were measured using a LI-COR LI7000 (LI-COR Biosciences, Lincoln, NE, USA) optical instrument, which measures infrared absorption in two wavelength bands around $5 \mu \mathrm{m}$, using a broadband light source and band pass filters. In these wavelength bands, both $\mathrm{H}_{2} \mathrm{O}$ and $\mathrm{CO}_{2}$ absorb the radiation rather strongly. In order to overcome this interference, the instrument includes two cells. One is used for the sample and the other as a reference cell, containing known concentrations of $\mathrm{CO}_{2}$ and $\mathrm{H}_{2} \mathrm{O}$. The $\mathrm{CO}_{2}$ concentration in the sample cell is obtained by calculating the light absorption, due to $\mathrm{CO}_{2}$ and $\mathrm{H}_{2} \mathrm{O}$ by comparing the intensities in the sample and reference cells. The calibration curve was checked by a span gas calibration with three known $\mathrm{CO}_{2}$ gas concentrations in the measurement range (i.e. $370,395,420 \mathrm{ppmv}$ ). The air sampling flow rate of the LI-COR instrument is around $6 \mathrm{~L} \mathrm{~min}^{-1}$, while the flow for the reference gas is $150 \mathrm{~mL} \mathrm{~min}^{-1}$. Depending on the pump speed, this instrument can have a faster response than the $\mathrm{SO}_{2}$ analyser, i.e. the $t_{90}$ is lower than $5 \mathrm{~s}$. For calibration, a single analytical standard mixture of $\mathrm{CO}_{2}$ in air (395 ppmv), together with nitrogen (less than $1 \mathrm{ppmv} \mathrm{CO}_{2}$ content) is needed as a gas for the reference cell and zero calibration, respectively. Instrument accuracy: $\pm 0.08 \mathrm{ppm}$.

The $\mathrm{NO}-\mathrm{NO}_{\mathrm{x}}$ measurement was performed by a THERMO ELECTRON model 42C (Thermo Electron Corporation, Franklin, MA, USA) that measures NO by the chemiluminescence reaction between ozone and NO. Normally, the instrument works in a dual channel principle. In one channel, the air passes for some seconds through a heated Mo-catalyst (which converts $\mathrm{NO}_{2}$ to $\mathrm{NO}$ ), and hence, the resulting signal represents the sum of $\mathrm{NO}$ and $\mathrm{NO}_{2}$ $\left(\mathrm{NO}_{\mathrm{X}}\right)$. In the second channel, $\mathrm{NO}$ is measured exclusively by bypassing the Mo-converter. In order to increase the response time to a $t_{90}$ of about $15 \mathrm{~s}$, the time constant was changed to $1 \mathrm{~s}$. This setting does not allow for the measurement of $\mathrm{NO}$ and $\mathrm{NO}_{\mathrm{x}}$ together. Therefore, two identical instruments were used, one measuring $\mathrm{NO}$ and the other measuring total $\mathrm{NO}_{\mathrm{x}}$. For calibration, a reference gas mixture of $200 \mathrm{ppbv} \mathrm{NO}$ in $\mathrm{N}_{2}$ was applied. Instrument accuracy: $\pm 10 \%$.

Particle counting was performed by a TSI 3007 portable CPC (TSI Incorporated, Shoreview, MN, USA). The device operates in the $0.01-1 \mu \mathrm{m}$ size range and the $0-100000 \mathrm{~cm}^{-3}$ concentration range, which is suitable for ship plume measurements. During the measurements, the device was never saturated by an excessive number of particles. Instrument accuracy: $\pm 10 \%$.

Size-segregated particulate matter was collected with an $\mathrm{MS} \& \mathrm{~T}^{\mathrm{TM}}$ impactor (Air Diagnostics and Engineering Inc., Harrison, ME, USA) at an aerosol size-range of $\mathrm{PM}_{10}$. Pallflex-type TK15-G3M membrane filters (Pall Life Sciences, Ann Arbor, MI, USA) with $0.3 \mu \mathrm{m}$ pore-size and $37 \mathrm{~mm}$ diameter were applied. Each impactor unit was attached to a vacuum pump (Air Diagnostics and Engineering Inc.), operated at a flow-rate of $10 \mathrm{~L} \mathrm{~min}^{-1}$. The air-flows 
were checked daily with a calibrated rotameter. The sampled air volume was registered with standard gasmeters.

Independent filter sampling was performed during ship plume events (plume filters) and between the plume events (background filters). These events were clearly recognised by observing the sharp increase of $\mathrm{CO}_{2}$ level after the passing of a ship upwind of the monitoring point. The difference between plume and background filter concentrations provides the species' mixing ratio in the plume.

Since the amount of aerosol sampled during a single plume event (duration: max. 3-4 min) was not enough for chemical analysis, the aerosols of several plume events were collected on each "plume" filter. Thus, a $\mathrm{PM}_{10}$ "plume" filter corresponds roughly to one day average emission of the ships (average of 37-75 ships).

The aerosol-loaded filters (plume and background) were subjected to secondary target X-ray fluorescence analysis (XRF), for the determination of the elemental content of the samples (especially focusing on $\mathrm{Ni}$ and $\mathrm{V}$, which are atmospheric tracers of heavy fuel oil combustion). The measurement was implemented by a tube excited XRF system using a SIEMENS diffraction tube with Mo anode and Mo secondary target. The fluorescence spectrum was recorded by a KETEK AXAS-A X-ray detector (KETEK GmbH, Munich, Germany). For quantitative analysis, the sensitivity curve of the measurement system was recorded by measuring a series of standard thin Ni and V foils (NIST, Gaithersburg, MD, USA).

Since XRF analysis is considered to be a non-destructive analytical technique, the samples measured by XRF could be subject to further alternative analysis. Ion chromatography (IC) analysis was performed on the filters by a Dionex Model DX-120 (Dionex, Sunnyvale, CA, USA) ion chromatograph, equipped with Dionex IonPack CS16 cation and AS14 anion exchanger columns and a CDM-3 conductivity detector. For sample introduction, both the standard and sample solutions were injected through a $20 \mu \mathrm{L}$ loop. The eluents applied for the anion and cation exchangers were $3.5 \mathrm{mM} \mathrm{Na}_{2} \mathrm{CO}_{3}$ plus $1.0 \mathrm{mM} \mathrm{NaHCO}_{3}$, and $17 \mathrm{mM} \mathrm{H}_{2} \mathrm{SO}_{4}$, respectively. The flow rates were 1.2 and $1.0 \mathrm{~mL} \mathrm{~min}^{-1}$ for the anion and the cation column, respectively. For suppressing the conductivity of the eluent, the ASRS-300 and CSRS-300 ULTRA suppressors were applied for the anion and cation exchanger, respectively. Calibration was made against two sets of multi-ion standard solutions, each consisting of five solutions of either the anions or the cations, respectively. Three replicate measurements were performed for each sample/standard solution, from these data the average value and the standard deviation were calculated. The precision of the analysis was better than $3.6 \%$. Certified Multi anion and Multi cation Standard Solutions of PRIMUS (Sigma-Aldrich, 210 Steinheim, Switzerland) as reference materials were applied for verifying the accuracy of the IC method.

The filters were exposed to ultrasonic aided leaching in $5 \mathrm{~mL}$ ultrapure water (Milli-Q) in a Bransonic Model 2210 ultrasonic bath (Branson, Danbury, CT, USA). Each leachate solution was filtered through a Millex-GV syringe driven filter unit (Millipore, Carrigtwohill, Co. Cork, Ireland) with $0.22 \mu \mathrm{m}$ pore size to prevent any particles entering the IC columns. The leachates were analysed for their cationic and anionic content. Field blank filters were also analysed and used for blank corrections.

\subsection{Calculation of emission factors}

Emission factors of the components were calculated (in $\mathrm{g}$ emitted per $\mathrm{kg}$ fuel) for each detected plume passage. When an emission plume passed over the sampling point, the concentration peaks of pollutants were registered by the instruments. For EF calculation, the net peak areas were used (time integral of the concentrations over background). To generate the net peak area, a properly considered baseline is needed. For this purpose, the 1-2 min averages of the background concentrations before and after the plume events were taken as baseline, and their average values were subtracted from the total peak area.

Considering the molecular weight of carbon and sulphur dioxide, and the carbon mass percent in the fuel $(87 \pm 1.5 \%$; Cooper, 2005) the $\mathrm{SO}_{2} \mathrm{EF}$ can be expressed as:

$$
\begin{aligned}
\mathrm{EF}\left[\frac{\mathrm{g}}{\mathrm{kg}}\right] & =\frac{C\left(\mathrm{SO}_{2}\right)[\mathrm{ppb} \cdot s]}{C\left(\mathrm{CO}_{2}\right)[\mathrm{ppb} \cdot s]} \cdot \frac{64}{12} \cdot 0.87 \cdot 1000 \\
& =\frac{C\left(\mathrm{SO}_{2}\right)[\mathrm{ppb} \cdot s]}{C(\mathrm{CO} 2)[\mathrm{ppb} \cdot s]} \cdot 4640,
\end{aligned}
$$

where $C(\ldots)$ is the net time integral of the component's mixing ratio (over the background).

Since most of the fuel's sulphur content is emitted as $\mathrm{SO}_{2}$, the $\mathrm{SO}_{2} \mathrm{EF}$ can be converted to the fuel's sulphur content $(s)$ :

$s[\%]=\frac{32}{64} \cdot \mathrm{EF} \cdot 10^{-1}+R=\frac{1}{20} \cdot \mathrm{EF}+R$,

where $R$ represents the sulphur content that is emitted in other forms than $\mathrm{SO}_{2}\left(\mathrm{SO}_{3}\right.$ or particulate sulphate). This amount is generally lower than $6 \%$ of the fuel sulphur ratio (see Table 3).

The $\mathrm{NO}_{\mathrm{x}}$ EFs can be calculated based on the total nitrogen oxide concentration $\left(\mathrm{NO}+\mathrm{NO}_{2}\right.$, expressed as $\mathrm{NO}_{2}$ equivalent) compared to the $\mathrm{CO}_{2}$ concentration. Considering the molecular weights of these compounds and the mass percentage of carbon in ship fuel, the $\mathrm{NO}_{2}$ equivalent $\mathrm{EF}$ can be calculated as follows:

$$
\begin{aligned}
\mathrm{EF}\left[\frac{\mathrm{g}}{\mathrm{kg}}\right] & =\frac{\left(C(\mathrm{NO})[\mathrm{ppb} \cdot s]+C\left(\mathrm{NO}_{2}\right)[\mathrm{ppb} \cdot s]\right) \cdot 46}{C\left(\mathrm{CO}_{2}\right)[\mathrm{ppb} \cdot s] \cdot 12} \\
& \times 0.87 \cdot 1000 .
\end{aligned}
$$

Particle EFs, as well as element and water-soluble ionic EFs were also calculated based on their plume concentration normalised by the $\mathrm{CO}_{2}$ concentration. In case of element and ionic $\mathrm{EF}$, integration of several subsequent $\mathrm{CO}_{2}$ peak areas was necessary as it was described above. 
Table 1. Average EF of metal and water-soluble ionic components of aerosols observed in ship plumes. The unit is mg (kg fuel) ${ }^{-1}$.

\begin{tabular}{lcccccccccr}
\hline & $\mathrm{NO}_{3}{ }^{-}$ & $\mathrm{SO}_{4}{ }^{2-}$ & $\mathrm{Cl}^{-}$ & $\mathrm{Na}^{+}$ & $\mathrm{NH}_{4}{ }^{+}$ & $\mathrm{K}^{+}$ & $\mathrm{Mg}^{2+}$ & $\mathrm{Ca}^{2+}$ & $\mathrm{V}^{*}$ & $\mathrm{Ni}^{*}$ \\
\hline Sample A & $150 \pm 10$ & $570 \pm 30$ & $180 \pm 10$ & $180 \pm 10$ & $170 \pm 10$ & $10 \pm 1$ & $20 \pm 2$ & $70 \pm 7$ & $35 \pm 7$ & $22 \pm 4$ \\
Sample B & $190 \pm 10$ & $390 \pm 20$ & $380 \pm 10$ & $490 \pm 20$ & $60 \pm 10$ & $10 \pm 1$ & $40 \pm 4$ & $50 \pm 5$ & $16 \pm 3$ & $11 \pm 2$ \\
\hline * Deter
\end{tabular}

* Determined by XRF analysis.

Table 2. Elemental composition of a fuel sample delivered by the chief engineer of Stena Line.

\begin{tabular}{lr}
\hline & $\begin{array}{r}\text { Concentration } \\
\text { mg (kg fuel) }\end{array}$ \\
\hline Vanadium (V) & $34 \pm 2$ \\
Nickel (Ni) & $20 \pm 1$ \\
Calcium (Ca) & $16 \pm 0.8$ \\
Potassium (K) & $1 \pm 0.05$ \\
Sodium (Na) & $10 \pm 0.5$ \\
\hline
\end{tabular}

\section{Results and discussion}

During the campaign, altogether 497 plumes of 341 ships were measured. About half of the plumes were measured in a single case (only TNO), the other half in three or four cases $(\mathrm{TNO}+2 \mathrm{JRC}+\mathrm{Chalmers})$. If a plume was measured in multiple cases, average values were considered and the standard deviation was applied for uncertainty estimation. The average relative standard deviation (SD) of $\mathrm{SO}_{2}$ and $\mathrm{NO}_{\mathrm{x}} \mathrm{EF}$ was 23 and $26 \%$, respectively. These uncertainty values are composed by the errors of the concentration measurements (for $\mathrm{SO}_{2}, \mathrm{NO}_{\mathrm{x}}$ and $\mathrm{CO}_{2}$, see Sect. 2.2), and the calculation uncertainties (i.e. peak area calculation, baseline consideration). It should be mentioned that the main uncertainty of EF calculation comes from the way of $\mathrm{CO}_{2}$ baseline consideration. Calculation of the net peak area for $\mathrm{CO}_{2}$ was very sensitive to the baseline due to its high background value.

Some ships plumes were measured twice or more times during the campaign (e.g. Stena Line ferries two times each day, or port service ships many times a day). The average SD for the repeated $\mathrm{SO}_{2} \mathrm{EF}$ measurement was $30 \%$, while that of the $\mathrm{NO}_{\mathrm{x}} \mathrm{EF}$ measurement was $34 \%$. These SD values are slightly higher than the uncertainty of a single measurement. Considering that the circumstances of different emissions of a certain ship (fuel type, engine operating conditions, etc.) were not necessarily the same, these SD values demonstrate good repeatability of the measurements.

While $\mathrm{CO}_{2}$ is a chemically inert compound within the plume, the concentrations of $\mathrm{SO}_{2}$ and $\mathrm{NO}_{\mathrm{x}}$ are influenced by chemical conversion. The residence time of the plume in the atmosphere before reaching the measurement points has been calculated from the measured distances from the ships to the sampling points and the measured wind speeds as dis-

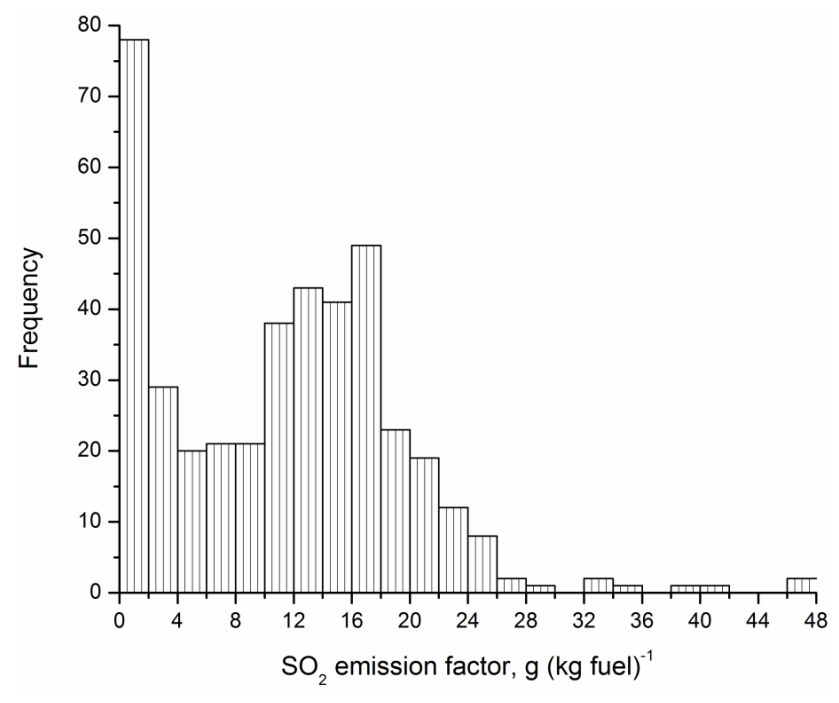

Fig. 8. Distribution of the $\mathrm{SO}_{2}$ emission factors of the ships under study. The total $\mathrm{SO}_{2}$ EF range was divided into $24 \mathrm{EF}$ bins. Frequencies of the EF bins are plotted along the y-axes.

cussed above; the average is $100 \mathrm{~s}$ and the maximum lies below $15 \mathrm{~min}$ (see Fig. 5). The potential influence of chemistry on the measurements can be estimated based on the work of Chen et al. (2005), who studied the conversion of $\mathrm{NO}_{\mathrm{x}}$ and $\mathrm{SO}_{2}$ in a ship plume during daytime on the 8 May, $100 \mathrm{~km}$ off the California coast and observed a significantly reduced atmospheric lifetime of $\mathrm{NO}_{\mathrm{x}}$, which was found to be as low as approximately $1.8 \mathrm{~h}$. Taking into account the different geographical location and time of the year, we consider the $\mathrm{NO}_{\mathrm{x}}$ lifetime measured in the Californian experiment to be an upper limit for that of the experiment in Rotterdam. Further, it must be taken into consideration that the $\mathrm{NO}_{\mathrm{x}}$ lifetime in the initial phase of the plume development is likely to be relatively long due to depletion of $\mathrm{OH}$. Assuming a $\mathrm{NO}_{\mathrm{x}}$ lifetime of $1.8 \mathrm{~h}$ a $1 \mathrm{~min}$ plume residence time will lead to an underestimation of the $\mathrm{NO}_{\mathrm{x}}$ emission factor by less than $1 \%$ which we consider to be negligible. If the residence time is $15 \mathrm{~min}$ the underestimation will be $13 \%$.

The lifetime of $\mathrm{SO}_{2}$ is longer than the lifetime of $\mathrm{NO}_{\mathrm{x}}$. Thus, although it is known that oxidation rates can be enhanced within plumes, we do not expect an important influence of the plume chemistry on the measured $\mathrm{SO}_{2}$ concentration because of the short time scale. 
Table 3. Emission factors (EF) for $\mathrm{SO}_{2}, \mathrm{SO}_{4}{ }^{2-}$, and particulate matter $(\mathrm{CN})$. Particulate sulphur ratios to the total fuel sulphur content were calculated from the $\mathrm{SO}_{4}{ }^{2-}$ to $\mathrm{SO}_{2}$ EF ratios. Mass median diameters (MMD) were calculated from the $\mathrm{SO}_{4}{ }^{2-}$ and $\mathrm{CN}$ EFs ratio assuming spherical particle shape and $1.84 \mathrm{~g} \mathrm{~cm}^{-3}$ density.

\begin{tabular}{|c|c|c|c|c|c|c|}
\hline & $\begin{array}{r}\text { Fuel S, } \\
\%\end{array}$ & $\begin{array}{r}\mathrm{SO}_{2} \mathrm{EF}, \\
\mathrm{g}(\mathrm{kg} \mathrm{fuel})^{-1}\end{array}$ & $\begin{array}{l}\mathrm{SO}_{4}{ }^{2-} \mathrm{EF} \\
\mathrm{g}(\mathrm{kg} \text { fuel })^{-1}\end{array}$ & $\begin{array}{l}\text { Particle S/ } \\
\text { Fuel S, \% }\end{array}$ & $\begin{array}{l}\mathrm{CN} \text { EF } 10^{16} \\
\left(^{(\mathrm{kg} \text { fuel })^{-1}}\right.\end{array}$ & $\begin{array}{r}\mathrm{MMD}, \\
\mathrm{nm}\end{array}$ \\
\hline Sample A & $0.32 \pm 0.07$ & $6.5 \pm 1.5$ & $0.57 \pm 0.03$ & 5.56 & n.a. & n.a. \\
\hline Sample B & $0.29 \pm 0.07$ & $5.9 \pm 1.4$ & $0.39 \pm 0.02$ & 4.26 & $1.05 \pm 0.1$ & $42.2^{c}$ \\
\hline Petzold (2008, test rig) & $2.21 *$ & 44.2 & $2.89^{\mathrm{m}}$ & 4.27 & $2.17^{*}, \mathrm{~d}$ & 52.1 \\
\hline Murphy $(2009$, in stack) & 2.98 & $59.7 *$ & $4.30 *$ & 4.58 & $1.3^{*}$ & 80.9 \\
\hline Agrawal (2008) & $2.05^{*}$ & 41.0 & $3.24^{\mathrm{w}}$ & 5.16 & n.a. & n.a. \\
\hline Moldanova (2009) & $1.95 *$ & 39.0 & $0.76^{*}$ & 1.28 & n.a. & n.a. \\
\hline
\end{tabular}

Note: n.a. - not available, * - original data taken from reference, $\mathrm{d}$ - difference of numbers of total particles and non-volatile particles, $\mathrm{w}$ - converted from $\mathrm{g} \mathrm{kW}^{-1} \mathrm{~h}^{-1}$ data using $\mathrm{CO}_{2} \mathrm{EF}, \mathrm{m}$ - converted from $\mathrm{mg} \mathrm{m}^{-3}$ data using $\mathrm{CO}_{2}$ mixing ratio, $\mathrm{c}$ - sulphate particle concentration was considered as the difference of $\mathrm{CN}$ and the interception of Fig. 10.

The distribution of the measured ships as a function of their duty type is presented in Fig. 7. As a comparison, information on the activity data and technology share of global bottom-up emission inventories, such as EDGARv4.2 (European Commission, 2011) were consulted, and the predicted distribution of duty types are presented in the figure. The EDGARv4.2 uses the bunker statistics of the International Energy Association (IEA) as input for the activity data and differentiates between the presences in ports and at sea based on Dalsøren et al. (2009). The EDGAR database associates for its international sea transport a high share to tanker, cargo, container ships and bulk carriers. Our finding verifies this apportionment of the global fleet, except the high contribution of bulk carriers, which appear with low frequency in the measurement results. It can be ascribed to the fact that these ships generally berth in Europort using the southern channel (see Fig. 3), thus they could be sampled from the ME location only for two days of the campaign. Another difference is that Inland and Patrol Vessel types are missing from the EDGAR database, however they correspond to EDGARS's Local Activity class.

It is to be mentioned that tankers, bulk carriers and container ships are also cargo ships. In this study, multipurpose ships are called "cargo ships" if they can carry containers and dry-bulk goods, while the term of "container ship" covers the fully cellular types of cargo ships. The term "tanker" covers all types of ships carrying liquids and/or gases.

\section{1 $\mathrm{SO}_{2}$ emission factor}

Figure 8 shows the distribution of $\mathrm{SO}_{2} \mathrm{EFs}$ among the ships. The entire $\mathrm{SO}_{2} \mathrm{EF}$ range was divided into 24 bins and the frequencies of the bins plotted along the y-axes. The distribution is bimodal, which indicates the existence of two ship classes with different $\mathrm{SO}_{2}$ emission characteristics. In the lower mode, the EF is lower than $6 \mathrm{~g}(\mathrm{~kg} \text { fuel })^{-1}$ which corresponds to a sulphur-to-fuel ratio of less than $0.3 \%$ (see Eq. 3). The low mode contains service and port authorities' ships, such as patrol vessels, tug boats and suction hoppers (local activity), as well as inland vessels that use low sulphur fuel. The high mode has a maximum around 14-

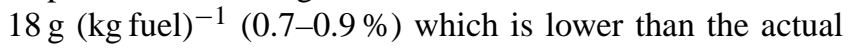
SECA emission limit value by $50-40 \%$. This class is formed by container and cargo ships, tankers and ferries (RO-RO, i.e. roll on-roll off passenger and cargo) that have generally one or more main engines for propulsion, and several auxiliary engines for manoeuvring and energy production. While main engines generally run with HFO with the allowed sulphur content (it was $1.5 \mathrm{~m} \mathrm{~m}^{-1} \%$ in SECA at the time of the study), auxiliary engines use lower sulphur fuels, marine diesel oil (MDO) or distilled diesel oil. The resultant $\mathrm{SO}_{2}$ $\mathrm{EF}$ is determined by the high $\mathrm{EF}$ of main engines and the low EF of auxiliary engines. Consequently, the resulting EF is always lower than the EF of the main engine, depending on its relative contribution to the total emission. The typical share of the auxiliary engine's fuel consumption of the total fuel consumption is about $10 \%$ at sea (Endersen et al., 2007; Whall et al., 2007), but can grow up to $45 \%$ during manoeuvring in ports (Whall et al., 2007). Taking these contribution values and also concerning 0.5 and $1.5 \%$ sulphur content of $\mathrm{MDO}$ and $\mathrm{HFO}$, respectively, the reduction of total $\mathrm{SO}_{2} \mathrm{EF}$ caused by auxiliary engines' contribution can be estimated as $6 \%$ at sea and $30 \%$ in ports.

Since our measurements were made at the entrance of the port, various contributions of auxiliary engines should be considered, from 6 to $30 \%$. Consequently, the higher EF mode is quite wide, including ships with an $\mathrm{SO}_{2} \mathrm{EF}$ between $8-30 \mathrm{~g}(\mathrm{~kg} \text { fuel })^{-1}$. Only seven ships were found with an EF above $30 \mathrm{~g}$ (kg fuel $)^{-1}$, corresponding to a fuel sulphur content higher than $1.5 \%$ (SECA limit). Thus, the number of exceedances was less than $2 \%$ of the total number of observations.

Figure 9 shows the $\mathrm{SO}_{2} \mathrm{EF}$ distribution according to the duty type of the ships. One can distinguish three $\mathrm{SO}_{2}$ emission ranges. The first, formed by inland vessels, for which the average $\mathrm{EF}$ is $\sim 1 \mathrm{~g}(\mathrm{~kg} \text { fuel })^{-1}(0.05 \%$ sulphur fuel content $)$. 


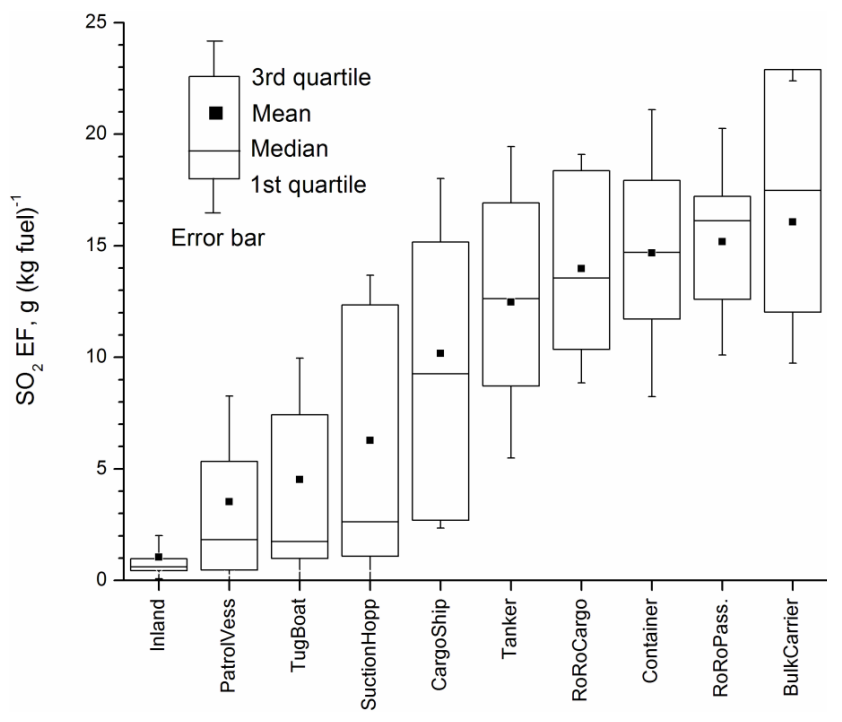

Fig. 9. $\mathrm{SO}_{2}$ EF distribution among duty type of the ships.

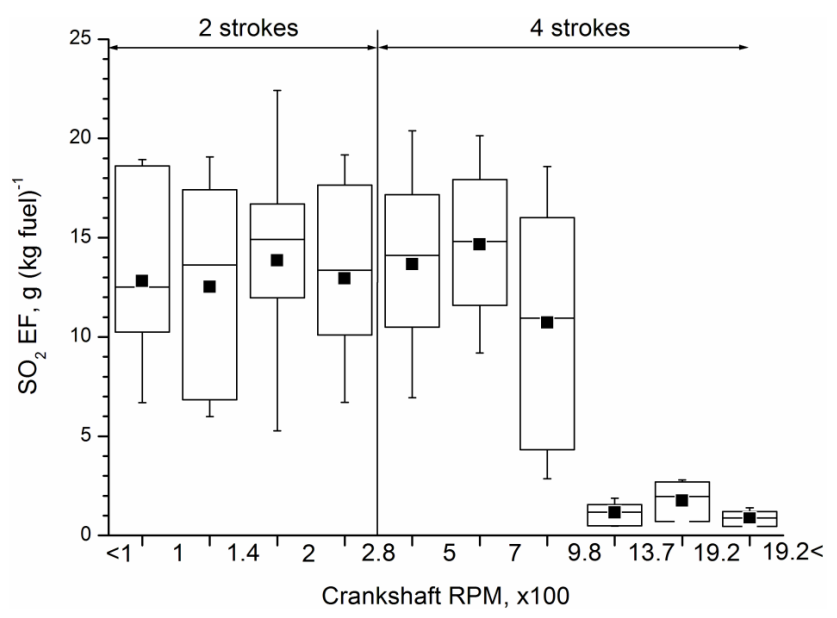

Fig. 10. $\mathrm{SO}_{2}$ EF distribution among crankshaft rpm of the engine. The crankshaft range was divided into 11 bins based on logarithmic scale. Average $\mathrm{SO}_{2}$ EFs of the bins are plotted along the y-axes, while sticks on the $\mathrm{x}$-axes refer the borders of the bins.

These ships use distilled diesel fuel. The second class contains port service ships like patrol vessels and tug boats with a 4-6 g (kg fuel $)^{-1}$ EF on average. Sea duty ships form the third class, with EFs ranging from 10 to $16 \mathrm{~g}(\mathrm{~kg} \text { fuel })^{-1}$ on average.

Figure 10 shows the $\mathrm{SO}_{2} \mathrm{EF}$ distribution against the operational crankshaft rotational speed. Since the crankshaft rotational speed distribution followed a lognormal trend, the whole range from 80 to 2100 rotations per min (rpm) was divided into 11 intervals based on a logarithmic scale. Borders of the rpm intervals are written along the $\mathrm{x}$-axis. Ranges of 2 strokes and 4 strokes engines are marked. Inland vessels were excluded from the distribution, since they form a distinct $\mathrm{SO}_{2} \mathrm{EF}$ class.

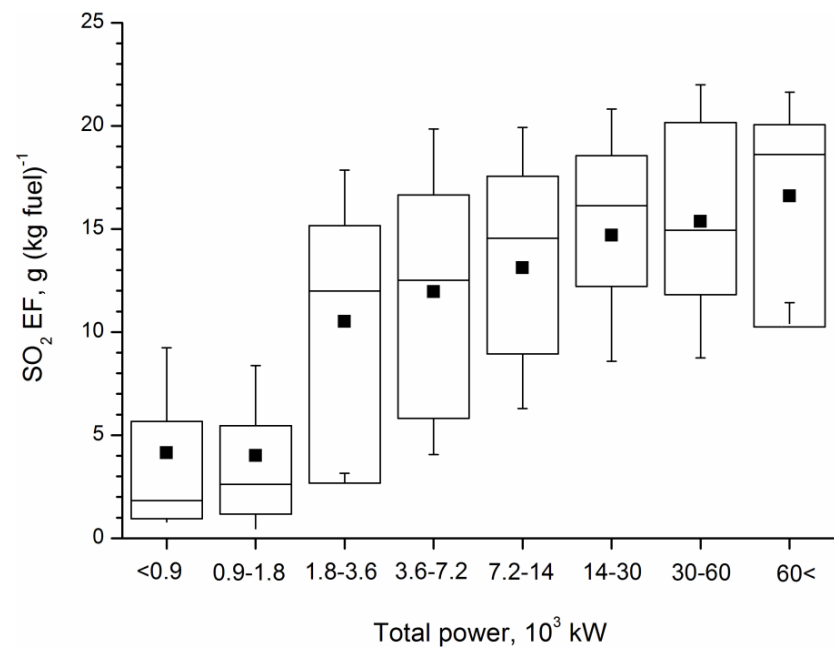

Fig. 11. The $\mathrm{SO}_{2}$ EF distribution with the engine power of the ships. The power range of the ships was divided into 8 intervals based on logarithmic scale. Average $\mathrm{SO}_{2} \mathrm{EFs}$ of the bins are plotted along the $y$-axes, while power bins are marked on the $\mathrm{x}$-axes.

As it can be seen in the figure, there is no overlap between the rotational speed ranges of two strokes and four strokes engines, and no significant difference can be observed for $\mathrm{SO}_{2}$ EFs between the two engine types. Below $700 \mathrm{rpm}$ the $\mathrm{SO}_{2} \mathrm{EF}$ is $13-14 \mathrm{~g}(\mathrm{~kg} \text { fuel })^{-1}$, independently from the stroke number of the engine. Between 700 and $980 \mathrm{rpm}$, the $\mathrm{SO}_{2} \mathrm{EF}$ suddenly decreases down to $1-2 \mathrm{~g}(\mathrm{~kg} \text { fuel })^{-1}$. Most of the port service ships that use low sulphur content fuel have high speed engines. These ships form the last three classes, with engine speed higher than $980 \mathrm{rpm}$.

The engine power of the studied ships ranged from 400 to $80000 \mathrm{~kW}$, following a lognormal distribution. The power range was divided into 8 intervals based on a logarithmic scale. The average $\mathrm{SO}_{2} \mathrm{EF}$ of each power bin is plotted along the y-axes of Fig. 11. The first two intervals with low EFs refer to the local activity ships that generally have engines with low or moderate power. Over $1800 \mathrm{~kW}$, the EF jumps over $10 \mathrm{~g} \mathrm{(kg} \mathrm{fuel})^{-1}$ and then gradually increases up to $16 \mathrm{~g}(\mathrm{~kg}$ fuel $)^{-1}$. The reason for the obviously growing trend of $\mathrm{SO}_{2}$ $\mathrm{EF}$ in the $1800-80000 \mathrm{~kW}$ range is not clear; it might be explained by the decreasing contribution of auxiliary engines to the total emission. The higher the power of the main engine, the lower the relative contribution of auxiliary engines, which eventually causes a higher $\mathrm{SO}_{2} \mathrm{EF}$.

Following the EMEP/EEA 2009 (CORINAIR) recommendations, EDGARv4.2 classifies the different vessel types in two categories: (1) the low momentum (power) category, grouping Local Activity, Tug Boat and Suction Hopper, and (2) the high momentum (power) category, grouping the rest. The CORINAIR estimates $10 \mathrm{~g}$ (kg fuel $)^{-1} \mathrm{SO}_{2} \mathrm{EF}$ for category (1), while $52.5 \mathrm{~g}$ (kg fuel) ${ }^{-1} \mathrm{SO}_{2} \mathrm{EF}$ for category (2) as a global average (including SECA). These two categories can be identified in Figs. 9 and 11, with obviously lower 


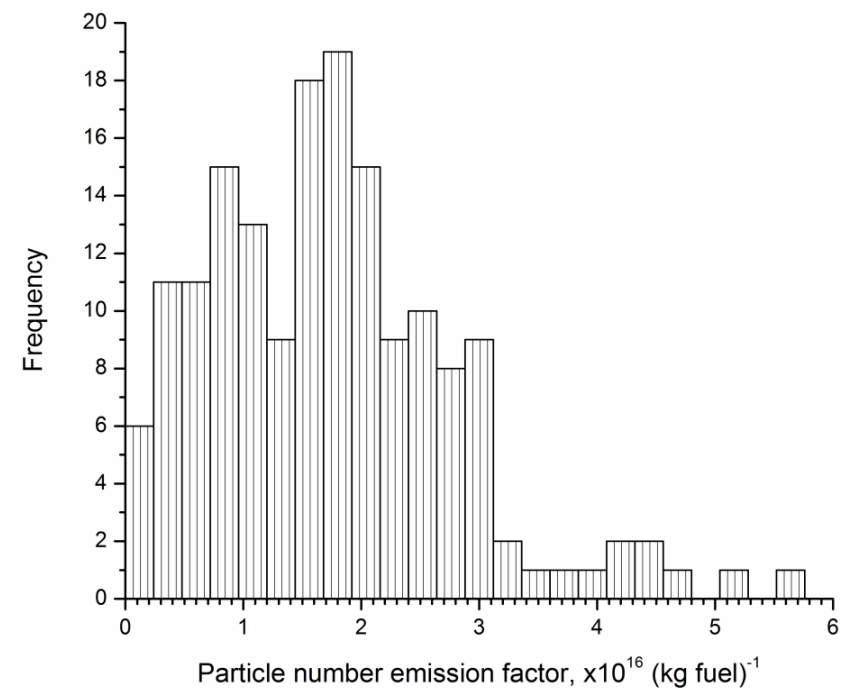

Fig. 12. Distribution of particle emission factors of the studied ships. The total particle EF range was divided into 24 EF bins. Frequencies of the EF bins are plotted along the y-axes.

$\mathrm{SO}_{2} \mathrm{EF}$, since our measurements were performed in SECA. The gap between category (1) and (2) is about tenfold in EDGARv4.2, while we found only threefold increase, due to the lower sulphur limit in the SECA.

\subsection{Particle emission factor}

Since a minor part of the sulphur content of the fuel is emitted in particulate form, the distribution of the particle $\mathrm{EF}$ is similar to that of $\mathrm{SO}_{2}$ (Fig. 12). As for $\mathrm{SO}_{2}$, the emission factor distribution is bimodal, with a maximum at $0.8 \times 10^{16}(\mathrm{~kg}$ fuel $)^{-1}$ (low sulphur fuel) and $1.8 \times 10^{16}(\mathrm{~kg} \text { fuel })^{-1}$ (high sulphur fuel). Sinha et al. (2003) reported particle EFs for ships in the range from $1.2-6 \times 10^{16}(\mathrm{~kg} \mathrm{fuel})^{-1}$, which covers the higher mode of the present results.

Average particle and $\mathrm{SO}_{2} \mathrm{EFs}$ were calculated for each $\mathrm{SO}_{2}$ emission factor interval of Fig. 8. A linear trend was observed between the average particle and $\mathrm{SO}_{2}$ EFs (Fig. 13). Coloured polygons represent results reported in the literature, while the green circle marks the value what we calculated averaging over the same time when aerosol filter sample $\mathrm{B}$ was collected. The slope of the linear regression, which is fitted to the EF results of the present study (black dots) may be interpreted as the EF of sulphate particles, while the intercept corresponds to the EF of other particle types (e.g. soot, organic, ash) at zero sulphur content.

However, it has also been found that the emission of organic particulate matter increases by higher fuel sulphur content (Lack et al., 2009, 2011). This means that the slope of the regression line can be considered as the upper limit of sulphate particles, while real EF can be lower depending on the ratio of organic particles.

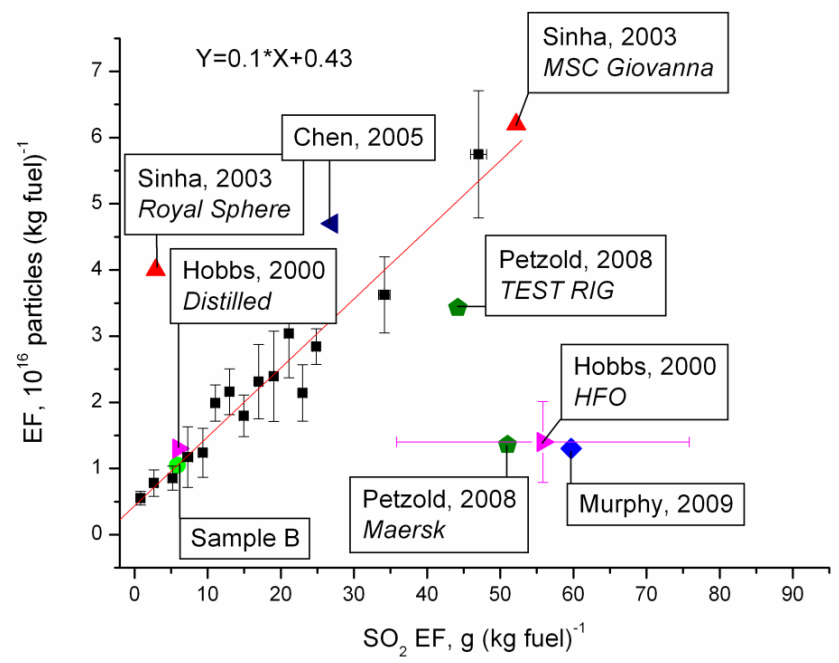

Fig. 13. Particle emission factor as a function of $\mathrm{SO}_{2} \mathrm{EF}$ (black dots). Literature data are represented by coloured polygons. Error bars represent standard deviations. Slope of the regression line: $0.1 \pm 0.01$, intercept: $0.48 \pm 0.09, R^{2}: 0.97$.

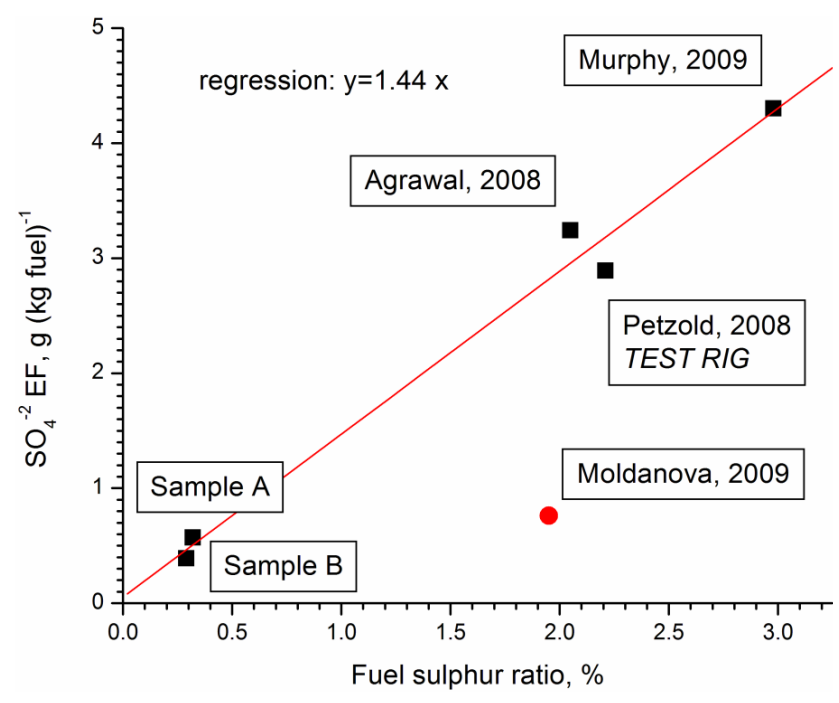

Fig. 14. The $\mathrm{SO}_{4}{ }^{2-} \mathrm{EF}$ as a function of fuel sulphur ratio. Red dot marks an outlier that was ignored during the regression calculation. Slope of the regression line: $1.44 \pm 0.1$, intercept forced to be zero, $R^{2}: 0.98$.

It has to be noted that these sulphate and non-sulphuric particle EFs are averages over the measured fleet at given conditions. Sulphate and soot EFs depends on the combustion conditions, after treatment, engine load (Petzold et al., 2008, 2010), etc.; thus EFs for a particular ship can vary significantly.

Apart from the test rig measurements of Petzold et al. (2008), all other literature values in Fig. 13 have been obtained by air borne measurements of emissions from ships sailing on the open sea. Petzold et al. (2008) and Murphy 
et al. (2009) measured emissions from a container ship, and also Msc Giovanna, observed by Sinha et al. (2003), is a container ship; all of these vessels are using marine fuel oil. The two data from Hobbs et al. (2000) are an average of three container ships and three bulk carriers using marine fuel oil, the other point is a navy ship using a distilled fuel. In the first case the standard deviations are marked by error bars. Also the tanker "Royal Sphere", observed by Sinha et al. (2003) used a distilled fuel. The ships that create the plume observed by Chen et al. (2005) were only partially identified. The information available about these ships and their operational conditions do not offer any obvious explanation of the differences that are observed in Fig. 13 for the relation between particle and $\mathrm{SO}_{2}$ emission rates. Murphy et al. (2009) reported that their CPCs, were saturated in the centre of the plume. This gives a possible explanation for the lower EF values reported by them. On the other hand Petzold et al. (2008) finds that coagulation has an important influence on the particle number concentration in the initial phase of the plume; they observed a decrease around $50 \%$ of the apparent particle emission factor within $10 \mathrm{~min}$. Taking into consideration the plume ages in the reported studies, it seems that the influence of coagulation could well explain the fact that some of the points reported in the literature lie well below those found in the present study, where the plumes had a relatively short residence time before encountering the measurement point.

Another parameter that may have a relevant influence on the observed number concentrations is the lower limit of the particle diameter that can be detected by the measurement devices. We do not know the size distribution of the particles measured in the present study, however based on the several observed particle size distributions of ship plumes in ambient air (i.e. having been subject to hygroscopic growth) published by Hobbs et al. (2000), Petzold et al. (2008) and Murphy et al. (2009), it can be concluded that the part below $10 \mathrm{~nm}$ is typically small but not always negligible. In fact, Murphy et al. (2009) reports evidence of a significant contribution of particles in the range between 3 and $10 \mathrm{~nm}$ diameter. One may speculate that the very high ratio of particle number concentration to $\mathrm{SO}_{2}$ emission factor in the plume of "Royal Sphere" may be due to an important contribution of ultrafine particles.

The strong and statistically significant $(p>0.01)$ linear relationship found in Fig. 13 for ships using fuels spanning a wide range of sulphur contents is potential useful for predicting particle emissions from ships. However, it will need to be confirmed by more studies of particle emission factors of ships under different operational conditions for the ship, but with a similar (short) residence time of the plume in air. According to the study by Petzold et al. (2010), engine load has a significant influence on particle number emission factors and, thus the observed linear relationship may be a result of the fact that the ships observed in this experiment operate at moderate engine loads, not at the extreme limits.
The slope of the linear regression curve is $10^{15}$ particles per gram $\mathrm{SO}_{2}$. Assuming that all of the fuel sulphur content is emitted as $\mathrm{SO}_{2}$, this slope is equivalent to $2 \times 10^{18}$ particles per $1 \mathrm{~kg}$ sulphur burnt, or $(s / 100 \mathrm{~kg} \text { fuel })^{-1}$, where $s$ is the fuel sulphur content in percent. The intercept is $\sim 4.8 \times 10^{15}$ $(\mathrm{kg} \text { fuel })^{-1}$, which may be used as an estimate of particle emissions at zero fuel sulphur content.

In order to assess the water-soluble ionic and elemental EF of ships, the aerosol samples were chemically analysed. Due to the difficulties of aerosol sampling (short time of plume passages), only two plume-background sample pairs were taken during the campaign. Since the amount of the aerosol collected during a single ship passage was very low, particles emitted by successive ships were accumulated on the same filter. The plumes of 51 and 75 ships were collected on the filters. The average $\mathrm{CO}_{2}$ plume concentrations of the same ships were calculated, and subsequently, average ionic and metal EFs were derived.

Table 1 summarises the water-soluble ionic and metallic composition of the average plumes, calculated as a difference between the plume and the background concentrations.

The two filters show similar nitrate and sulphate EF. Comparing $\mathrm{K}^{+}, \mathrm{Ca}^{2+}, \mathrm{V}$ and $\mathrm{Ni} \mathrm{EFs}$ with the fuel composition delivered by the chief engineer of Stena Line (Table 2), we find that they are at the same order of magnitude. Concerning $\mathrm{Na}$, EF values were 20-50 times higher compared to the concentration in the fuel sample. This indicates the presence of an additional source apart from the fuel.

In Table 3 the sulphate EFs are compared to literature values. $\mathrm{SO}_{2}$ and particle number (condensation nuclei or $\mathrm{CN}$ ) EFs are also included. Particulate sulphur was compared to the total sulphur content of the fuel (fourth column). From the $\mathrm{SO}_{4}{ }^{2-}$ and $\mathrm{CN}$ EFs the mass median diameter (MMD) of sulphate particles were calculated by assuming spherical shaped particles with a density of $1.84 \mathrm{~g} \mathrm{~cm}^{-3}$.

It can be concluded that we measured lower $\mathrm{SO}_{4}{ }^{2-} \mathrm{EFs}$ compared with the literature values, due to a lower sulphur content of the fuel used in SECA. Particulate sulphur to total fuel sulphur ratios are in the $4.26-5.56 \%$ interval, except those from Moldanova et al. (2009), who reported a lower $\mathrm{SO}_{4}{ }^{2-}$ EF. A possible explanation of this may be that Moldanova et al. (2009) performed the measurement in a cooled dilution system, in which $\mathrm{H}_{2} \mathrm{SO}_{4}$ and $\mathrm{SO}_{3}$ may be lost through condensation.

The linear relationship between the fuel sulphur content and $\mathrm{SO}_{4}{ }^{2-} \mathrm{EF}$ is presented in Fig. 14. In addition to the three literature values for the high sulphur content domain (Agrawal, 2008; Petzold et al., 2008; Murphy, 2009), we present two values from the low sulphur content range. The points fit to a common regression line that describes the relationship between fuel sulphur content and $\mathrm{SO}_{4}{ }^{2-} \mathrm{EF}$. The value obtained by Moldanova et al. (2009) was not included in the regression calculation.

The slope of the regression line indicates that $144 \mathrm{~g} \mathrm{SO}_{4}{ }^{2-}$ is produced for each $\mathrm{kg}$ sulphur that is burnt with the fuel. 


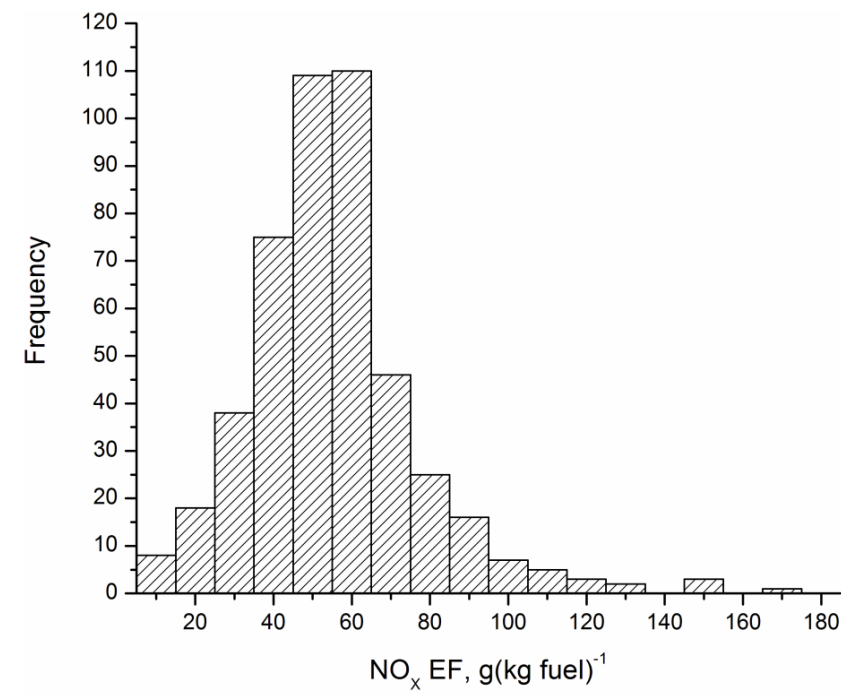

Fig. 15. Distribution of the $\mathrm{NO}_{\mathrm{x}}$ emission factor among the measured ships. The total $\mathrm{NO}_{\mathrm{x}} \mathrm{EF}$ range was divided into $18 \mathrm{EF}$ bins. Frequencies of the EF bins are plotted along the y-axes. $\mathrm{NO}_{\mathrm{x}} \mathrm{EF}$ values are represented as $\mathrm{NO}_{2}$ equivalent.

Lack et al. (2009) studied the relationship between fuel sulphur content and $\mathrm{SO}_{4}{ }^{2-} \mathrm{EF}$ on a statistically significant fleet. They obtained $140 \mathrm{~g} \mathrm{SO}_{4}{ }^{2-}$ per $\mathrm{kg}$ sulphur, which is in an excellent agreement with this value. This agreement is found in spite of the fact that that the observations by Lack et al. (2009) were made in a non-SECA area and on the open sea.

Combined with the number of particles produced from burning $1 \mathrm{~kg}$ sulphur with the fuel $\left(2.0 \times 10^{18}\right.$, i.e. the slope of Fig. 13) the average mass of particles could be calculated. When assuming spherical particles of sulphuric acid with a density of $1.84 \mathrm{~g} \mathrm{~cm}^{-3}$, the average mass could be converted to a MMD of $41.8 \mathrm{~nm}$. This value is close to the MMD value that was directly calculated from the $\mathrm{SO}_{4}{ }^{2-}$ and $\mathrm{CN}$ EFs for Sample B and Petzold's test rig data (Table 3), but only the half of the MMD that were calculated from Murphy's data. This may be explained by the effects of coagulation or by saturation of the CPC, as discussed above.

It has to be noted that we might overestimate the sulphate particle number from Fig. 13, which may refer to both sulphate and organic particles (see the discussion above of this figure). It means that the $\sim 42 \mathrm{~nm}$ can be seen as a lower limit for the average diameter of sulphate particles (excluding particles with a diameter below $10 \mathrm{~nm}$, not detected by these measurements).

\section{3 $\quad \mathrm{NO}_{\mathrm{x}}$ emission factor}

While the $\mathrm{SO}_{2}$ and sulphate EFs depend on the fuel sulphur content, the $\mathrm{NO}_{\mathrm{x}}$ EF mainly depends on the burning conditions of the engine and (slightly) on the fuel composition because heavy fuel oil contains some nitrogen-containing com-

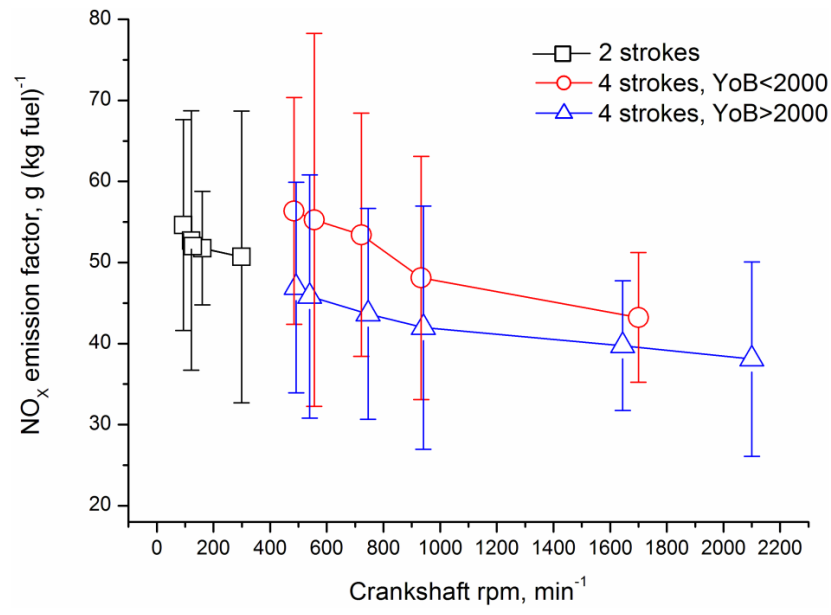

Fig. 16. The $\mathrm{NO}_{\mathrm{x}} \mathrm{EF}$ against crankshaft rpm. Values for two strokes engines and four strokes engines built before and after year 2000 were plotted in different colours. Error bars refer the standard deviations of $\mathrm{NO}_{\mathrm{x}} \mathrm{EF}$ in RPM bins. $\mathrm{NO}_{\mathrm{x}} \mathrm{EF}$ values are represented as $\mathrm{NO}_{2}$ equivalent.

pounds (Nagai and Kawakami, 1989) that contribute to the $\mathrm{NO}_{\mathrm{x}}$ emission.

Ships sailing cross the entrance of the port generally applied moderate load as it could be concluded from the average speed of the observed ships that was calculated to be 10 knots. For comparison, the typical design speed of a large container ship is about 25 knots (MAN, 2009), while the design speeds of bulk carriers lie in the range from 11 knots for the smallest ones to approximately 14.5 knots for the larger ones (MAN, 2010).

The average $\mathrm{NO}_{\mathrm{x}} \mathrm{EF}$ was found to be $53.7 \mathrm{~g}$ (kg fuel) ${ }^{-1}$ ( $\mathrm{NO}_{2}$ equivalent). Its distribution among the measured ships is shown in Fig. 15. The distribution is monomodal, Gaussian, with a maximum at $60 \mathrm{~g}$ (kg fuel) ${ }^{-1}$. The majority of ships (more than $50 \%$ ) have a $\mathrm{NO}_{\mathrm{x}}$ emission factor between $40-70 \mathrm{~g}(\mathrm{~kg} \text { fuel })^{-1}$.

This result is in agreement with $\mathrm{NO}_{\mathrm{x}}$ emission factor calculations for different vessel types by the EDGARv4.2 based on the EMEP/EEA 2009 (CORINAIR) recommendations. The calculations yield an average $\mathrm{NO}_{\mathrm{x}}$ emission factor of about $52 \mathrm{~g} \mathrm{(kg} \mathrm{fuel)})^{-1}$.

The recent study of Williams et al. (2009) on a statistically significant fleet provides higher $\mathrm{NO}_{\mathrm{x}} \mathrm{EF}$ values. They measured at $\sim 87 \mathrm{~g}(\mathrm{~kg} \text { fuel })^{-1}$ average $\mathrm{EF}$ for bulk carriers, while our value is $\sim 43 \mathrm{~g} \mathrm{(kg} \mathrm{fuel})^{-1}$. Similarly, they measured significantly higher EF for tankers at $\sim 79 \mathrm{~g}(\mathrm{~kg} \text { fuel })^{-1}$

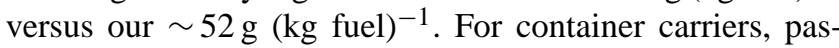
senger ships and tugs they measured at $\sim 60 \mathrm{~g}(\mathrm{~kg} \text { fuel })^{-1}$, which is comparable with our $51 \mathrm{~g}(\mathrm{~kg} \text { fuel })^{-1}$. Williams et al. (2009) did not find a dependence of EFs on engine speed or load, despite considerable variability.

The average $\mathrm{NO}_{\mathrm{x}}$ EF was calculated and plotted in Fig. 16 against the crankshaft rpm (using the same bins as used 


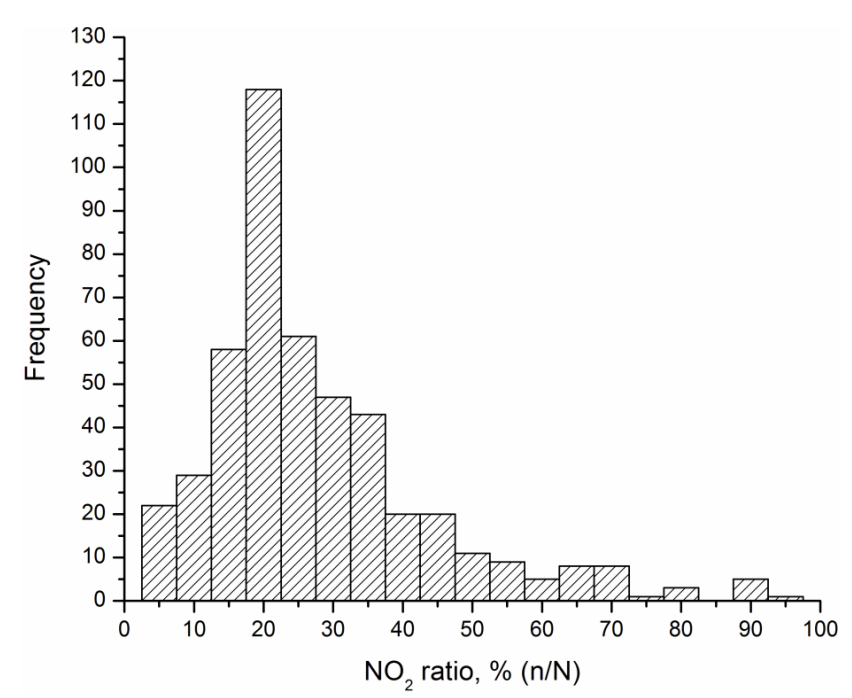

Fig. 17. Distribution of the $\mathrm{NO}_{2} / \mathrm{NO}_{\mathrm{x}}$ molar ratio among the studied ships. The total molar ratio range was divided into 19 bins. Frequencies of the bins are plotted along the y-axes.

before in Fig. 10). SDs per bins are also displayed. Ships with two strokes and four strokes engines are separated, because of the differences in the combustion conditions of the two types of engines. Since Tier $1 \mathrm{NO}_{\mathrm{x}}$ emission regulation has come into force in $2000, \mathrm{NO}_{\mathrm{x}} \mathrm{EFs}$ are plotted separately for ships which were built (YoB) before and after 2000. No statistically significant differences could be observed between ships with a two-stroke engine built before or after 2000 . Therefore, the EFs for these ships were plotted together.

As for ships with four-stroke engines, the $\mathrm{NO}_{\mathrm{x}} \mathrm{EF}$ for ships built before 2000 are higher than those for ships built after 2000 . The difference is especially significant within the low crankshaft rpm range (500-700 rpm).

A clearly decreasing trend in the $\mathrm{NO}_{\mathrm{x}} \mathrm{EF}$ could be observed with increasing crankshaft rpm. This is due to the fact that combustion takes more time in low speed engines than in faster engines, so a larger portion of nitrogen from air can be oxidised.

The molar $\mathrm{NO}_{2}$-to- $\mathrm{NO}_{\mathrm{x}}$ emission ratio, calculated from the mixing ratios of the two components in the plume $(\%$, $\mathrm{n} / \mathrm{N}$ ), is presented in Fig. 17. As can be seen, nitrogen oxides are mostly emitted as $\mathrm{NO}$, the ratio of $\mathrm{NO}_{2}$ emission is less than $25 \%$ at the majority of the ships.

As Fig. 18 demonstrates, the $\mathrm{NO}_{2}$-to- $\mathrm{NO}_{\mathrm{x}}$ emission ratio does not depend on the ambient ozone concentration, indicating that the oxidation of $\mathrm{NO}$ to $\mathrm{NO}_{2}$ in the fresh plume was probably of little importance. In the figure, diurnal averages of $\mathrm{NO}_{2}$-to- $\mathrm{NO}_{\mathrm{x}}$ ratios were calculated and plotted for the plume and outside of the plume separately. Diurnal averages of ozone concentrations are plotted as well. The hourly average concentrations of ambient atmospheric trace gases were provided by the air quality monitoring station operated by the local authority on air pollution (DCMR Environmental

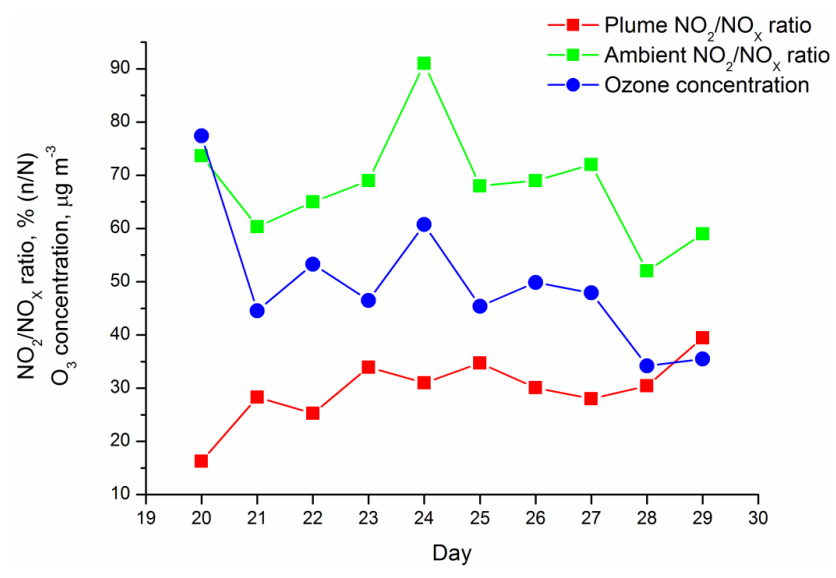

Fig. 18. Diurnal averages of ambient and plume $\mathrm{NO}_{2} / \mathrm{NO}_{\mathrm{x}}$ molar ratios and ozone concentrations during the measurement campaign. Concentration data between 8.00 and 20.00 were concerned for the averaging.

Protection Agency, Rijnmond, Port of Rotterdam) in the $20 \mathrm{~m}$ vicinity of the sampling location at Hoek van Holland. Using the hourly averages, diurnal averages were created considering the periods where plume measurements were taken (between 8.00 and 20.00).

It can be seen that the ambient $\mathrm{NO}_{2}$-to- $\mathrm{NO}_{\mathrm{x}}$ ratio correlates with the ozone concentration, while the plume ratio oscillates between 15 and $40 \%$ independently of the ozone concentration. This indicates that the more oxidative atmosphere results in a higher $\mathrm{NO}_{2}$ ambient ratio at longer time scales, while it does not significantly affect the composition of the fresh plume.

\section{Summary and conclusions}

A ship emission survey on a statistically relevant fleet is reported. The plumes of the passing ships were measured at the entrance of the port of Rotterdam (Hoek van Holland). The concerned components were $\mathrm{SO}_{2}, \mathrm{NO}, \mathrm{NO}_{2}$ and particulate matter. The $\mathrm{CO}_{2}$ concentrations in the plumes were measured in order to normalise the emission factors for fuel consumption.

\subsection{Gaseous emission factors}

Distributions of $\mathrm{SO}_{2}, \mathrm{NO}_{\mathrm{x}}$ and particulate matter EFs were calculated according to ship duty type, main engine power and crankshaft rotational speed. Inland vessels, port service boats, and sea duty ships form a discrete $\mathrm{SO}_{2} \mathrm{EF}$ group. No significant differences were found between $\mathrm{SO}_{2} \mathrm{EFs}$ of twostroke and four-stroke engines. A clearly increasing trend was found for $\mathrm{SO}_{2} \mathrm{EF}$ with the engine power of the ships, possibly due to a decreased relative contribution of auxiliary engine emissions on high powered ships. 
The average $\mathrm{NO}_{\mathrm{x}}$ EF was found to be $\sim 54 \mathrm{~g}(\mathrm{~kg} \text { fuel })^{-1}$ which is in agreement with the EDGARv4.2 database. The $\mathrm{NO}_{\mathrm{x}} \mathrm{EF}$ decreases with an increasing crankshaft rotational speed. Significantly lower $\mathrm{NO}_{\mathrm{x}} \mathrm{EFs}$ were found for fourstroke ships built after 2000, fulfilling Tier 1 regulation of MARPOL.

It was found that nitrogen oxides were emitted mainly as $\mathrm{NO}$, while the $\mathrm{NO}_{2}$ emission was around $20 \%$ of the $\mathrm{NO}_{\mathrm{x}}$ emission. The observed $\mathrm{NO}_{2}$-to-NOx ratio in the plume did not depend on the ambient ozone concentration, while outside of the plume this ratio correlated with ozone concentration. This indicates that the ozone driven $\mathrm{NO}-\mathrm{NO}_{2}$ conversion requires more time before it significantly influences the composition of the fresh plume so the observed ratio in the plume is that of the stack emissions.

\subsection{Emission factors for particles and sulphate}

A linear relationship was found between the $\mathrm{SO}_{2} \mathrm{EF}$ (or fuel $S$ content) and the particle number EF. The slope of the regression line tells us that on average about $2 \times 10^{18}$ particles are formed for $1 \mathrm{~kg}$ sulphur burnt, while the intercept indicates that about $4.8 \times 10^{15}$ non-sulphuric particles (soot, ash, etc.) are emitted for $1 \mathrm{~kg}$ fuel burnt at zero sulphur content.

The filter sulphate measurements represented ships which are powered by fuel with a low sulphur content (less than $1 \%)$, while other authors reported results for high sulphur contents (2-3\% fuel S). However, both were found to be proportional to the corresponding fuel sulphur ratio. The proportionality factor was found to be $144 \mathrm{~g}$ sulphate per $1 \mathrm{~kg}$ sulphur burnt with the fuel. This means that $\sim 4.8 \%$ of the total sulphur content is emitted in particle form (i.e. sulphate), or transformed to particulate form immediately after emission from the stack.

The mass median diameter of sulphate particles was estimated from the particle number and sulphate EFs as $\sim 42 \mathrm{~nm}$.

\subsection{Outlook}

The global average of fuel sulphur content composed by SECA and non-SECA zones was $2.2 \%$ for the year 2000 according to Eyring et al. (2010). This value will decrease in the future according to the sulphur content regulations in SECA and non-SECA. Assuming that the traffic distribution between the zones will not change, the average sulphur content will follow the trend plotted in Fig. 1 (black line). Applying global fuel consumption data for the year 2001 Eyring et al. (2005) calculated the annual $\mathrm{SO}_{2}$ emission of marine traffic. This value can be transformed to annual $\mathrm{SO}_{4}{ }^{2-}$ emission using the slope of Fig. 14. The obtained $792 \mathrm{Gg} \mathrm{yr}^{-1}$ agrees with Eyring's $786 \mathrm{Gg} \mathrm{yr}^{-1}$ value (Eyring et al., 2005) that were calculated using the observations of Petzold et al. (2004) of the composition of particle emissions from a test bed diesel engine. In contrast Lack et al. (2009) estimated a significantly lower value of $412 \mathrm{Gg} \mathrm{yr}^{-1}$.
The predicted variation of the $\mathrm{SO}_{4}{ }^{2-}$ annual emission over the coming years is presented in Fig. 1. We emphasise that in addition to the direct emission of $\mathrm{SO}_{4}{ }^{2-}$ an important contribution to sulphate aerosols in the marine troposphere comes from the oxidation of $\mathrm{SO}_{2}$ emitted by ships.

It can be also concluded that the remote (e.g. from the shore) analysis of plume composition could be an efficient tool in hands of authorities to check the sulphur limit compliance of the ships.

Acknowledgements. The authors would like to acknowledge the collaboration with Stena Line and in particular the support from the chief engineer Dick Van Der Ent. Special thanks for Sebastiao Martins for his effort in equipping the expedition. The Dutch agency DCMR is thanked for providing ozone concentration data from the station. Finally we thank The European Commission, DG Environment, for financing the project "Remote surveillance of ship emissions of sulphur dioxide" which provided the framework for the present study.

Edited by: A. Richter

\section{References}

Agrawal, H., Malloy, Q. G. J., Welch, W. A., Miller, J. W., and Cocker, D. R.: In-use gaseous and particulate matter emissions from a modern ocean going container vessel, Atmos. Environ., 42, 5504-5510, 2008.

Berg, N., Mellqvist, J., Jalkanen, J.-P., and Balzani, J.: Ship emissions of $\mathrm{SO}_{2}$ and $\mathrm{NO}_{2}$ : DOAS measurements from airborne platforms, Atmos. Meas. Tech., 5, 1085-1098, doi:10.5194/amt-51085-2012, 2012.

Chen, G., Huey, L. G., Trainer, M., Nicks, D., Corbett, J., Ryerson, T., Parrish, D., Neumann, J. A., Nowak, J., Tanner, D., Holloway, J., Brock, C., Crawford, J., Olson, J. R., Sullivan, A., Weber, R., Schauffler, S., Donnelly, S., Atlas, E., Roberts, J., Flocke, F., Hubler, G., and Fehsenfeld, F.: An investigation of the chemistry of ship emission during ITCT 2002, J. Geophys. Res., 110, D10S90, doi:10.1029/2004JD005236, 2005.

Cofala, J., Amann, M., Heyes, C., Klimont, Z., Posch, M., Schopp, W., Tarasson, L., Jonson, J., Whall, C., and Stavrakaki, A.: Final Report: Analysis of Policy Measures to Reduce Ship Emissions in the Context of the Revision of the National Emissions Ceilings Directive, March 2007, International Institute for Applied Systems Analysis, Laxenburg, Austria, p. 74, 2007.

Cohen, A. J., Anderson, H. R., Ostro, B., Pandey, K. D., Krzyzanowski, M., Kunzli, N., Gutschmidt, K., Pope, A., Romieu, I., Samet, J. M., and Smith, K.: The global burden of disease due to outdoor air pollution, J. Toxicol. Environ. Health, A, 68, 1301-1307, 2005.

Cooper, D. A.: HCB, PCB, PCDD and PCDF emissions from ships, Atmos. Environ., 39, 4901-4912, 2005.

Corbett, J. J., Winebrake, J. J., Green, E. H., Kasibhatla, P., Eyring, V., and Lauer, A.: Mortality from ship emissions: a global assessment, Environ. Sci. Technol., 41, 8512-8518, 2007.

Dalsøren, S. B., Eide, M. S., Endresen, Ø., Mjelde, A., Gravir, G., and Isaksen, I. S. A.: Update on emissions and environmental 
impacts from the international fleet of ships: the contribution from major ship types and ports, Atmos. Chem. Phys., 9, 21712194, doi:10.5194/acp-9-2171-2009, 2009.

Duyzer, J., Hollander, K., Verhagen, H., Weststrate, H., Hensen, A., Kraai, A., and Koos, G.: Assessment of emissions of PM and $\mathrm{NO}_{\mathrm{x}}$ of sea going vessels by field measurements, TNO report $\mathrm{nr}$ 2006-A-R0341/B, 2006.

Endersen, Ø., Sorgard, E., Behrens, H. L., Brett, P. O., and Isaksen, I. S. A.: A historical reconstruction of ships' fuel consumption and emissions, J. Geophys. Res., 112, D12301, doi:10.1029/2006JD007630, 2007.

European Commission: Joint Research Centre, Netherlands Environmental Assessment Agency: Emission Database for Global Atmospheric Research (EDGAR), release version 4.2., available at: http://edgar.jrc.ec.europa.eu, 2011.

Eyring, V., Kohler, H. W., van Aardenne, J., and Lauer, A.: Emissions from international shipping: 1 . The last 50 years, J. Geophys. Res., 110, D17305, doi:10.1029/2004JD005619, 2005.

Eyring, V., Isaksen, I. S. A., Berntsen, T., Collins, W. J., Corbett, J. J., Endresen, Ø., Grainger, R. G., Moldanova, J., Schlager, H., and Stevenson, D. S.: Transport Impacts on Atmosphere and Climate: Shipping, Atmos. Environ., 44, 4735-4771, 2010.

Hobbs, P. V., Garrett, T. J., Ferek, R. J., Strader, S. R., Hegg, D. A., Frick, G. M., Hoppel, W. A., Gasparovic, R. F., Russell, L. M., Johnson, D. W., O'Dowd, C., Durkee, P. A., Nielsen, K. E., and Innis, G.: Emissions from ships with respect to their effects on clouds, J. Atmos. Sci., 57 2570-2590, 2000.

IMO: MEPC 59/INF.10, "Prevention of air pollution from ships", International Maritime Organization, Marine Environment Protection Committee, 2009.

IPCC: Climate Change 2007: impacts, adaptation and vulnerability. Contribution of Working Group II to the Fourth Assessment Report of the Intergovernmental Panel on Climate Change, in: Cambridge University Press, edited by: Parry, M. L., Canziani, O. F., Palutikof, J. P., van der Linden, P. J., and Hanson, C. E., Cambridge, UK, p. 976, 2007.

Lack, D. A., Corbett, J. J., Onasch, T., Lerner, B., Massoli, P., Quinn, P. K., Bates, T. S., Covert, D. S., Coffman, D., Sierau, B., Herndon, S., Allan, J., Baynard, T., Lovejoy, E., Ravishankara, A. R., and Williams, E.: Particulate emissions from commercial shipping: Chemical, physical, and optical properties, J. Geophys. Res., 114, D00F04, doi:10.1029/2008JD011300, 2009.

Lack, D. A., Cappa, C. D., Langridge, J., Bahreini, R., Buffaloe, G., Brock, C., Cerully, K., Coffman, D., Hayden, K., Holloway, J., Lerner, B., Massoli, P., Li, S.-M., McLaren, R., Middlebrook, A. M., Moore, R., Nenes, A., Nuaaman, I., Onasch, T. B., Peischl, J., Perring, A., Quinn, P. K., Ryerson, T., Schwartz, J. P., Spackman, R., Wofsy, S. C., Worsnop, D., Xiang, B., and Williams E.: Impact of fuel quality regulation and speed reductions on shipping emissions: Implications for climate and air quality, Environ. Sci. Technol., 45, 9052-9060, doi:10.1021/es2013424, 2011.

MAN: "Propulsion trends in container vessels", available at: http://www.mandieselturbo.com/files/news/filesof4672/ 5510-0040-01ppr_low.pdf (last access: 9 July 2013), 2009.

MAN: "Propulsion trends in bulk carriers", available at: http://www.mandieselturbo.com/files/news/filesof5479/ 5510-0007-02ppr_low.pdf (last access: 9 July 2013), 2010.
Mellqvist, J. and Berg, N.: Identification of Gross Polluting Ships. Final report to Vinnova: RG Report (Göteborg) No. 4, ISSN 1653 333X, Chalmers University of Technology, 2010.

Mellqvist, J. and Berg, N.: Airborne surveillance of sulphur and $\mathrm{NO}_{\mathrm{x}}$ in ships as a tool to enforce IMO legislation, Atmos. Meas. Tech., in preparation, 2011.

Mellqvist, J., Berg, N., and Ohlsson, D.: Remote surveillance of the sulfur content and $\mathrm{NO}_{\mathrm{x}}$ emissions of ships, Second international conference on Harbours, Air Quality and Climate Change (HAQCC) 2008, Rotterdam, 2008.

Moldanova, J., Fridell, E., Popovicheva, O., Demirdjian, B., Tishkova, V., Faccinetto, A., and Focsa, C.: Characterisation of particulate matter and gaseous emissions from a large ship diesel engine, Atmos. Environ., 43, 2632-2641, 2009.

Murphy, S. M., Agrawal, H., Sorooshian, A., Padro, L. T., Gates, H., Hersey, S., Welch, W. A., Jung, H., Miller, J. W., Cocker, D. R., Nenes, A., Jonsson, H. H., Flagan, R. C., and Seinfeld, J. H.: Comprehensive simultaneous shipboard and airborne characterisation of exhaust from a modern container ship at sea, Environ. Sci. Technol., 43, 4626-4640, 2009.

Nagai, T. and Kawakami, M.: Reduction of $\mathrm{NO}_{\mathrm{x}}$ Emission in Medium-speed Diesel Engines, Warrendale, PA, Society of Automotive Engineers, 1989.

Petzold, A., Feldpausch, P., Fritzsche, L., Minikin, A., Lauer, P., and Bauer, H.: Particle emissions from ship engines, European Aerosol Conference, Budapest, HU, 6-10 September 2004, J. Aerosol Sci., 35, suppl. 2, S1095-1096, 2004.

Petzold, A., Hasselbach, J., Lauer, P., Baumann, R., Franke, K., Gurk, C., Schlager, H., and Weingartner, E.: Experimental studies on particle emissions from cruising ship, their characteristic properties, transformation and atmospheric lifetime in the marine boundary layer, Atmos. Chem. Phys., 8, 2387-2403, doi:10.5194/acp-8-2387-2008, 2008.

Petzold, A., Weingartner, E., Hasselbach, J., Lauer, A., Kurok, C., and Fleischer, F.: Physical Properties, Chemical Composition, and Cloud Forming Potential of Particulate Emissions from a Marine Diesel Engine at Various Load Conditions, Environ. Sci. Technol., 44, 3800-3805, 2010.

Segers, A. and Duyzer, J. H.: Ratio of $\mathrm{SO}_{2} / \mathrm{CO}_{2}$ from ships emission, TNO internal report, 2007.

Sinha, P., Hobbs, P. V., Yokelson, R. J., Christian, T. J., Kirckstetter, T. W., and Bruintjes, R.: Emissions of trace gases and particles from two ships in the southern Atlantic Ocean, Atmos. Environ., 37, 2139-2148, 2003.

Whall, C., Stavrakaki, A., Ritchie, A., Green, C., Shialis, T., Minchin, W., Cohen, A., and Stokes, R.: Ship emissions inventory - Mediterranean Sea. CONCAWE Final Report, Entec UK Limited, London, England, 2007.

Williams, E. J., Lerner, B. M., Murphy, P. C., Herndon, S. C., and Zahniser, M. S.: Emissions of $\mathrm{NO}_{\mathrm{x}}, \mathrm{SO}_{2}, \mathrm{CO}$ and $\mathrm{HCHO}$ from commercial marine shipping during Texas Air Quality Study (TexAQS) 2006, J. Geophys. Res., 114, D21306, doi:10.1029/2009JD012094, 2009. 